\title{
Microbial composition in seasonal time series of free tropospheric air and precipitation reveals community separation
}

\author{
Nora Els (D) Catherine Larose - Kathrin Baumann-Stanzer • Romie Tignat-Perrier • \\ Christoph Keuschnig • Timothy M. Vogel • Birgit Sattler
}

Received: 25 January 2019/Accepted: 26 August 2019/Published online: 4 September 2019

(C) The Author(s) 2019

\begin{abstract}
Primary biological aerosols are transported over large distances, are traveling in various media such as dry air masses, clouds or fog, and eventually deposited with dry deposition, especially for larger particles, or precipitation like rain, hail or snow. To investigate relative abundance and diversity of airborne bacterial and fungal communities, samples have been collected with a liquid impinger (Coriolis $\mu$ ) from the top of Mount Sonnblick (3106 m asl, Austrian Alps) from the respective sources under a temporal aspect over four seasons over the year to include all climatic conditions. Bacterial and fungal
\end{abstract}

Electronic supplementary material The online version of this article (https://doi.org/10.1007/s10453-019-09606-x) contains supplementary material, which is available to authorized users.

N. Els $(\bowtie) \cdot$ B. Sattler

Institute of Ecology, University of Innsbruck, Innsbruck, Austria

e-mail:nora.els@uibk.ac.at

N. Els · B. Sattler

Austrian Polar Research Institute, Vienna, Austria

C. Larose $\cdot$ R. Tignat-Perrier · C. Keuschnig ·

T. M. Vogel

Environmental Microbial Genomics, Laboratoire Ampère, École Centrale de Lyon, Université de Lyon, Écully, France

K. Baumann-Stanzer

Zentralanstalt für Meteorologie und Geodynamik, Vienna, Austria samples (16S rRNA and ITS) were sequenced using Illumina MiSeq paired-end sequencing, investigated for relative abundance by qPCR(16S rRNA and $18 \mathrm{~S}$ rRNA) and ice nucleation activity. Results show that there is no stable free tropospheric air microbial community and air mass origin was different for the four sampling periods which exerted influence on the microbial composition of the atmosphere although a core microbiome could be identified consisting of 61 bacterial OTUs and eight fungal genera. Differentiation between seasons was stronger pronounced in air than in precipitation, with rain being most different and variable of precipitation types, indicating distinct forces driving microbial fate in the air. Microorganisms precipitated with snow, hail or rain or being transported by clouds differ in their species composition from free tropospheric air masses and do not mirror the air community structure. They were more diverse, distinct in composition, 16S:18S ratio and abundance from free-floating PBA. Hence, snow or cloud samples are not suitable proxies for free tropospheric air microbiome composition, since separation processes in aerosolization, transport and scavenging occur. The microbial composition of arriving precipitation or clouds represents only a part of the microbial air composition communities of the cumulative sources of origin. Relative abundance and composition of ice nucleation-active bacteria showed a higher share of relative \% reads of known ice nucleation-active bacteria present in all wet phases compared to air. Results propose a separation of IN- 
active reads with higher shares occurring in precipitation. This study presents the first comparison of free tropospheric bacterial and fungal abundance and diversity in time series of air over several seasons in contrast to various precipitation forms in the free troposphere.

Keywords Free troposphere 16 SrRNA .

18SrRNA · ITS · Precipitation · Aerobiology

\section{Introduction}

Knowledge about and scientific interest in the composition and abundance of primary biological aerosols (PBA) (e.g., airborne bacteria and fungi) is rapidly increasing (180\% increase in publications per year from 2000 to 2018, search term: "airborne bacteria"). Most aerobiology studies are restricted to groundbased sampling within the planetary boundary layer (PBL) or focus on extreme events such as heat events and dust storms (Fang et al. 2018; Jeon et al. 2011; Maki et al. 2017; Gat et al. 2017; Fierer et al. 2008; Bowers et al. 2013), civilization and health related questions, like disease spread (Park et al. 2014; Adams et al. 2015; Di Giulio et al. 2010; Kelley and Gilbert 2013; Hagan et al. 1995; Polymenakou 2012; Griffin 2007; Brown and Hovmøller 2002) or pollen events (Burge 2002; Damialis et al. 2015; Ziello et al. 2012; Clot 2003; Jäger 2000; Gioulekas et al. 2004; Sofiev et al. 2013; Hamaoui-Laguel et al. 2015). Microbial composition in air masses within the PBL is affected by ground emissions and mixing of air masses (Bowers et al. 2011; Carotenuto et al. 2017; Burrows et al. 2009a, b). Within the PBL (upper boundary around 100-1000 $\mathrm{m}$ above ground level, AGL), vertical mixing of air masses over mountainous terrain is driven by ground turbulence, thermal convection and dynamic forcing with strong diurnal and seasonal variations in elevation AGL and mixing force (Rotach et al. 2015). Above the PBL, laminar flowing air masses are stratified in the free troposphere (Wekker et al. 2015).

Studies focusing on free tropospheric air microbial communities often present data from single campaigns or few flights (Schmale and Ross 2015; Techy et al. 2010; Jimenez-Sanchez et al. 2018; Smith et al. 2018; Maki et al. 2017; Xia et al. 2013; Zweifel et al. 2012) and have shown that microbes present in the free troposphere might originate from long-range travel (Maki et al. 2017; Smith and David 2012; Smith et al. 2011, 2012; Smith 2013; Brown and Hovmøller 2002; Burrows et al. 2009a, b). Air masses above and below PBL differ significantly in microbial composition. Free tropospheric habitats tend to have more Firmicutes (Smith et al. 2018; Smith 2013), Proteobacteria, Burkholderiales (DeLeon-Rodriguez et al. 2013) and extremophile yeasts, Saccharomycetes and Microbotryomycetes (Els et al. 2019). While the existence of either a stable (DeLeon-Rodriguez et al. 2013) or a highly variable (Zweifel et al. 2012) extremophile free tropospheric PBA community is disputed, generally few studies addressing the question were mainly performed over marine and oceanic regions (DeLeon-Rodriguez et al. 2013). Data on free tropospheric continental background PBA composition and variation are even more sparse due to numerous infrastructural challenges, like accessability, need of aerial vehicles, suitable technologies for sufficient air sampling volume and challenging meteorological conditions. Thus, insight into seasonal variability and free-floating PBA composition compared to cloud and precipitation composition in free tropospheric conditions is limited.

Microorganisms are not only ubiquitous in dry air masses, but also in clouds (Amato et al. 2005, 2017; Joly et al. 2014; Evans et al. 2019; Fuzzi et al. 1997), snow (Amato et al. 2007a, b; Honeyman et al. 2018; Elster et al. 2007; Harding et al. 2011; Larose et al. 2010), hail (Temkiv et al. 2012; Vali 1971; Michaud et al. 2014) and rain (Christner et al. 2008a, b; Huffman et al. 2013). Their densities and diversity are higher in wet air masses and precipitation than in clear air due to source of moisture (Xia et al. 2013; Evans et al. 2019). Aerosolized microorganisms can act as cloud condensation nuclei (Bauer et al. 2003) and be incorporated in clouds. Clouds likely offer a more hospitable environment due to water availability and nutrients (Delort et al. 2017; Deguillaume et al. 2008; Bianco et al. 2016). Bacteria might be able to multiply (Sattler et al. 2001) and degrade substances (Lallement et al. 2018) in cloud doplets.

Microorganisms could even trigger their aerosolization and precipitation voluntarily by ice nucleation (IN) capacity as part of their life cycle, which was observed to express in enhanced concentrations of PBA and biological IN-activity in snow and 
rain (Morris et al. 2014; Christner et al. 2008a, b; Huffman et al. 2013; Pouzet et al. 2017; Stopelli et al. 2015).

A range of processes, such as aerosolisation (Alsved et al. 2018), vapor to liquid phase change, particle coalescence, in-cloud circulation, temperature regime, cloud lifetime, cloud trajectories, nucleation properties and local air composition at the site of precipitation, effect on the microbial composition of precipitation (Möhler et al. 2007).

Recent publications used snow (Cáliz et al. 2018; Weil et al. 2017) or cloud sampling (Maki et al. 2017; Jiaxian et al. 2019) as a proxy for free tropospheric air microbial composition. However, the insights gained from precipitation and cloud studies above PBL might not directly depict the patterns in free tropospheric microbial communities.

Before being collected on the ground, precipitation travels through the PBL, where an inversion layer of accumulated particles is concentrated at the upper PBL (Brunet 2017). Scavenging impacts the microbial composition of droplets that pick up local PBA, but also release particles during transport and sedimentation (Jang et al. 2018; Huffman et al. 2013). Belowcloud scavenging of aerosol particles by snow is a known important mechanism of wet deposition (Paramonov et al. 2011), with differing effectivity for chemical components based on the forms of precipitation (Zhang et al. 2013; Zikova and Zdimal 2016). Thus, the scavenging effect might also be selective for PBA of certain properties (e.g., size, hygroscopicity, density, sphericity and interface interactions) between precipitation types and thus foster a selection for specific PBA (Möhler et al. 2007).

This study presents the first comparison of free tropospheric bacterial and fungal abundance and diversity in time series of air over several seasons in contrast to various precipitation forms in the free troposphere. We further estimated the relative abundance and composition of ice nucleation-active bacteria in order to investigate whether the separation between air and precipitation forms in terms of ice nuclei can be observed on the molecular level, as it is observed on physical IN-effectivity.

\section{Materials and methods}

\subsection{Study site}

Samples were collected at the roof top terrace of Mount Sonnblick Observatory (3106 m asl.), Austria $\left(47^{\circ} 3^{\prime} 14^{\prime \prime} \mathrm{N}, 12^{\circ} 57^{\prime} 27^{\prime \prime} \mathrm{E}\right.$, Fig. 1a, b). This location is operated as a meteorological observatory and is member of Global Atmosphere Watch of the World Meteorological Organisation (WMO). The site is exhaust neutral, supplied by electricity from the valley and equipped with an elevated air outlet to enable undisturbed air measurements. The vegetation in the valley consists of high alpine forest and shrubs that are dominated by pine (Pinus cembra, Pinus mugo, Pinus silvestris) and spruce (Picea abies, Picea montana). The closest settlement is the village Rauris village, which is $15 \mathrm{~km}$ away. The area within $100 \mathrm{~km}$ perimeter around the Sonnblick Observatory is sparsely populated.

In May, a complete snow cover was prevailing in the valley and on the mountain with high fresh snowfall $(50-100 \mathrm{~cm})$ before the sampling period, in August no snow cover was present at the mountain site or the valley, and in November and February a deep snow cover was present at the mountain site as well as at valley floor.

\subsection{Air and precipitation sampling}

A total of 17 snow, ten cloud samples, two rain and one hail sample were collected (Table 1). In total, 48 air samples comprising $288 \mathrm{~m}^{3}$ air were taken on four sampling campaigns in the months of May (2 to 5 May 2017, 13 samples, $78 \mathrm{~m}^{3}$ ), August (3 to 6 August 2017, 11 samples, $66 \mathrm{~m}^{3}$ ), November $(27$ November to 1 December 2017, 12 samples, $72 \mathrm{~m}^{3}$ ) and February (20 to 23 February 2018, 13 samples, $78 \mathrm{~m}^{3}$ ) approximately every $4 \mathrm{~h}$. We used a liquid impinger (Coriolis $\mu$, bertin Technologies, Montigny-le-Bretonneux, France) at a flow rate of $300 \mathrm{~L} \mathrm{~min}^{-1}$ for $10 \mathrm{~min}$ (i.e., $3 \mathrm{~m}^{3}$ each) into separate sterile vials filled with $15 \mathrm{~mL} 0.2 \mu \mathrm{m}$ filtered, distilled water. Before each sampling for sequencing, one run was taken as decontamination purging. Two temporally close samples (i.e., within the same hour) of three cubic meters each were pooled to account for low cell density in high elevations. Sampling could not always be conducted at the planned 4-hour interval, due to strong 

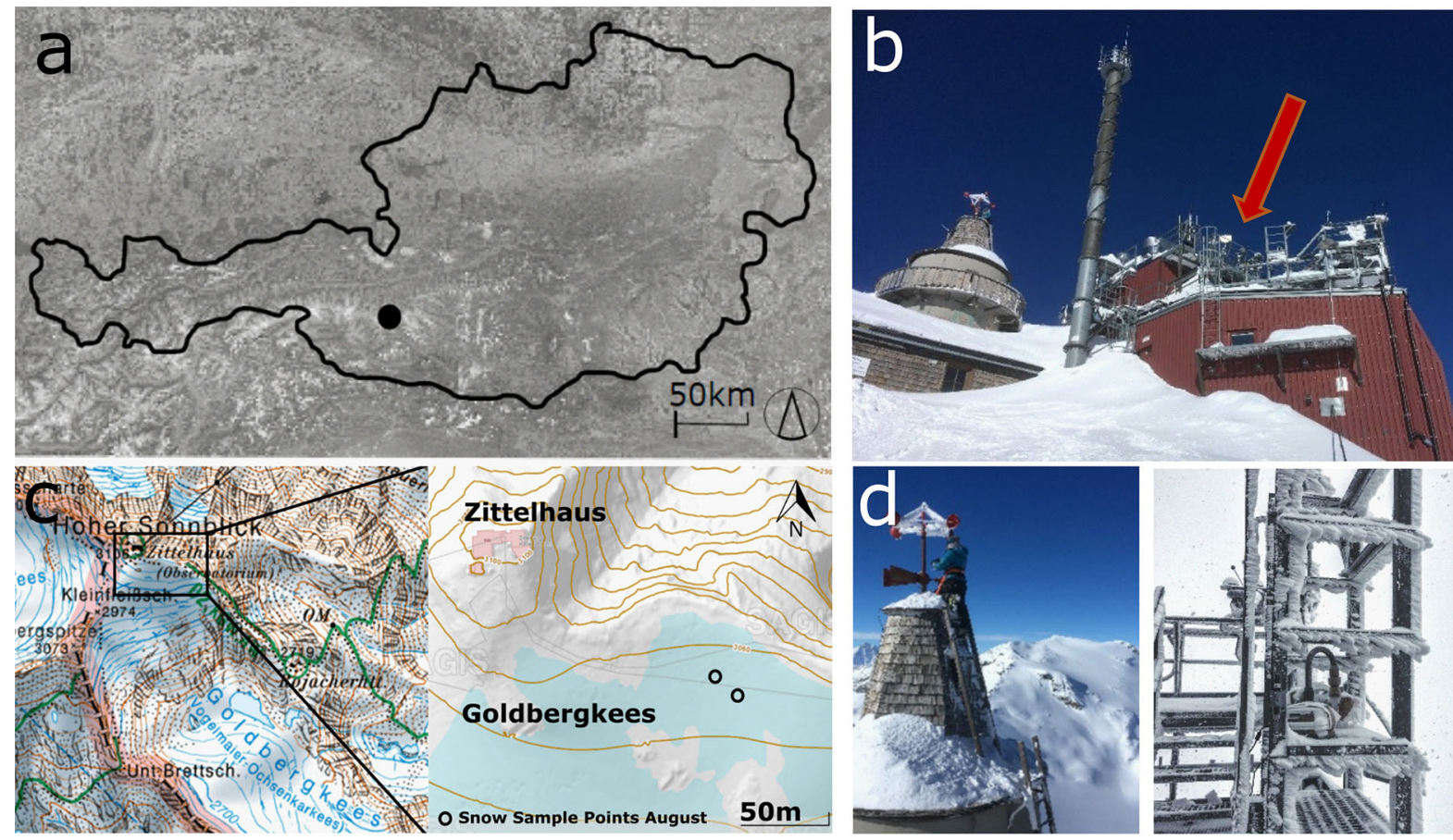

Fig. 1 a Location of mount Sonnblick in Austria, b location of the sampler on the roof terrace of the observatory, $\mathbf{c}$ location of August snow (slush) sample points, source:www.salzburg.gv.at/

winds or precipitation events or too cold temperatures which hampered the functionality of the sampling device (compare Table 1).

Snow was sampled into sterile Nasco Whirl-Pak (Roth, Karlsruhe, Germany) after fresh snow fall with a stainless steel shovel (Roth, Karlsruhe, Germany). Before each sampling, we rinsed the shovel three times with $0.2 \mu \mathrm{m}$ filtered milli-Q and turned it ten times in the snow, like the type of snow we would then sample, to precontaminate, usually this was conducted around $2 \mathrm{~m}$ apart from the actual sampling site. Thus, the idea of precontamination was to dispose non-site microbes and cover the shovel with the microbes we wanted to sample before the actual sampling. The shovel was kept in a sterile Nasco Whirl-Pak (Roth, Karlsruhe, Germany) for transport, to avoid contamination, and was washed three times with $\mathrm{HCl}(15 \%)$ and milli-Q before taken to the field. We did not use $\mathrm{EtOH}$, as this can leave remnants that can then interfere with the aquatic chemistry measurements, we also conducted with these samples. Only the uppermost fresh snow layer was sampled. sagisonline, $\mathbf{d}$ rime ice (supercooled atmospherical liquid water droplets frozen on surfaces) sampling from roof and railing

In August, slush (melting snow and ice) was sampled from the upper section of the Goldbergkees, in approx. $500 \mathrm{~m}$ direct distance from the observatory (see map Fig. 1c). Cloud water (i.e., supercooled atmospherical liquid water droplets) was collected as rime ice frozen to the railing and meteorological devices on the roof terrace and tower and roof of the observatory (see picture for sampling illustration and locations in Fig. 1d) with a precontaminated stainless steel shovel (Roth, Karlsruhe, Germany) into sterile Nasco Whirl-Pak (Roth, Karlsruhe, Germany). Rime in direct contact with surfaces was not sampled. Rain was sampled as wet deposition in a WADOS (wet and dry only precipitation sampler, Kroneis $\mathrm{GmbH}$, Vienna, Austria) as a 24-h cumulative sample at 10:00 $\mathrm{h}$ the 5.8.2017 and 6.8.2017, respectively. Hail was collected directly into sterile Nasco Whirl-Pak (Roth, Karlsruhe, Germany) during a strong thunderstorm event on the 5.8.2017 (20:00 h). 
Table 1 Sampling dates and times of analyzed air samples and precipitation, times indicated in UTC +1 (summer and winter time), samples were taken within one hour around indicated time

\begin{tabular}{|c|c|c|c|c|c|c|}
\hline \multicolumn{7}{|l|}{ May } \\
\hline \multirow[t]{2}{*}{02.05 .2017} & & & $\mathrm{~T} 1$ & $\mathrm{~T} 2$ & & Snow \\
\hline & & & $13: 00 \mathrm{~h}$ & $19: 00 \mathrm{~h}$ & & \\
\hline \multirow[t]{2}{*}{03.05 .2017} & $\mathrm{~T} 3$ & $\mathrm{~T} 4$ & T5 & T6 & $\mathrm{T} 7$ & Cloud \\
\hline & 07:00 h & $11: 00 \mathrm{~h}$ & $15: 00 \mathrm{~h}$ & $19: 00 \mathrm{~h}$ & $23: 00 \mathrm{~h}$ & \\
\hline \multirow[t]{2}{*}{ 04.05.2017 } & $\mathrm{T} 8$ & T9 & $\mathrm{T} 10$ & T11 & T12 & Cloud tower I, II \\
\hline & 07:00 h & $11: 00 \mathrm{~h}$ & $15: 00 \mathrm{~h}$ & $19: 00 \mathrm{~h}$ & $23: 00 \mathrm{~h}$ & Cloud terrace \\
\hline \multirow[t]{2}{*}{05.05 .2017} & $\mathrm{~T} 13$ & & & & & Snow \\
\hline & $07: 00 \mathrm{~h}$ & & & & & \\
\hline \multicolumn{7}{|l|}{ August } \\
\hline \multirow[t]{2}{*}{ 03.08.2017 } & & & & $\mathrm{T} 1$ & & \\
\hline & & & & $19: 00$ & & \\
\hline \multirow[t]{2}{*}{04.08 .2017} & $\mathrm{~T} 2$ & $\mathrm{~T} 3$ & $\mathrm{~T} 4$ & & & \\
\hline & 07:00 h & $11: 00 \mathrm{~h}$ & $15: 00 \mathrm{~h}$ & & & \\
\hline \multirow[t]{2}{*}{05.08 .2017} & T5 & T6 & $\mathrm{T} 7$ & T8 & & Slush snow I, II \\
\hline & 07:00 h & $13: 00 \mathrm{~h}$ & $15: 00 \mathrm{~h}$ & $19: 00 \mathrm{~h}$ & & \\
\hline \multirow[t]{2}{*}{06.08 .2017} & T9 & $\mathrm{T} 10$ & T11 & & & Rain, hail \\
\hline & 07:00 h & $11: 00 \mathrm{~h}$ & $15: 00 \mathrm{~h}$ & & & \\
\hline \multicolumn{7}{|l|}{ November } \\
\hline \multirow[t]{2}{*}{ 27.11.2017 } & & & & $\mathrm{T} 1$ & $\mathrm{~T} 2$ & Rain \\
\hline & & & & $19: 00 \mathrm{~h}$ & $23: 00 \mathrm{~h}$ & \\
\hline \multirow[t]{2}{*}{ 28.11.2017 } & T3 & $\mathrm{T} 4$ & T5 & T6 & & Snow \\
\hline & $07: 00 \mathrm{~h}$ & $11: 00$ & $15: 00 \mathrm{~h}$ & $19: 00 \mathrm{~h}$ & & \\
\hline \multirow[t]{2}{*}{ 29.11.2017 } & & $\mathrm{T} 7$ & $\mathrm{~T} 8$ & & & Cloud, snow \\
\hline & & $11: 00 \mathrm{~h}$ & $15: 00 \mathrm{~h}$ & & & \\
\hline \multirow[t]{2}{*}{30.11 .2017} & T9 & $\mathrm{T} 10$ & & $\mathrm{~T} 11$ & & Cloud I, II, Snow \\
\hline & $07: 00 \mathrm{~h}$ & $11: 00 \mathrm{~h}$ & & $19: 00$ & & \\
\hline \multirow[t]{2}{*}{01.12 .2017} & $\mathrm{~T} 12$ & & & & & Snow \\
\hline & 07:00 h & & & & & \\
\hline \multicolumn{7}{|l|}{ February } \\
\hline \multirow[t]{2}{*}{ 20.02.2018 } & & & $\mathrm{T} 1$ & $\mathrm{~T} 2$ & & Cloud, snow I, II \\
\hline & & & $16: 00 \mathrm{~h}$ & $19: 00 \mathrm{~h}$ & & \\
\hline \multirow[t]{2}{*}{ 21.02.2018 } & $\mathrm{T} 4$ & T5 & T6 & $\mathrm{T} 7$ & & Snow I, II, III \\
\hline & $07: 00 \mathrm{~h}$ & $11: 00 \mathrm{~h}$ & $15: 00 \mathrm{~h}$ & $19: 00 \mathrm{~h}$ & & Cloud, \\
\hline \multirow[t]{2}{*}{ 22.02.2018 } & $\mathrm{T} 8$ & T9 & $\mathrm{T} 10$ & T11 & & Snow I, II, III, IV \\
\hline & $07: 00 \mathrm{~h}$ & $11: 00 \mathrm{~h}$ & $15: 00 \mathrm{~h}$ & $19: 00 \mathrm{~h}$ & & Cloud \\
\hline \multirow[t]{2}{*}{ 23.02.2018 } & $\mathrm{T} 12$ & T13 & & & & \\
\hline & 07:00 h & $11: 00 \mathrm{~h}$ & & & & \\
\hline
\end{tabular}

\subsection{DNA extraction and sequencing}

Snow and cloud water were molten directly after sampling at room temperature $\left(20^{\circ} \mathrm{C}\right)$, and $1 \mathrm{~L}$ of molten sample was filtered though a $0.2 \mu \mathrm{m}$ polycarbonate filter (47 mm, Isopore, Merck, Darmstadt, Germany) as soon as liquid, and then stored frozen at $-20{ }^{\circ} \mathrm{C}$ until DNA extraction. The air samples, collected in $15 \mathrm{~mL}$ solution of sterile distilled water, were stored at $-20{ }^{\circ} \mathrm{C}$, until filtered 
on a $0.2 \mu \mathrm{m}$ polycarbonate filter $(47 \mathrm{~mm}$, Isopore, Merck, Darmstadt, Germany). DNA was extracted from the filters using DNeasy Power Water extraction kit (QIAGEN, Venlo, Netherlands) following the protocol provided with the kit, as this kit was stated to yield good results for aerobiological studies (Dommergue et al. 2019). Amplification, library prep (MiSeq Illumina sequencing, $2 \times 250 \mathrm{bp}$, Nextera XT Library Preparation Kit, Illumina, San Diego, USA) and sequencing were done with the Environmental Microbial Genomics group at the Laboratoire Ampère (ECL Lyon, University of Lyon, France). Community diversity was targeted: the V3-V4 region of the bacterial 16S rRNA SSU gene was amplified using 341F/785R (S-D-Bact-0341-b-S-17/S-D-Bact0785-a-A-21, Klindworth et al. 2013) primers, and the fungal internal transcribed spacer (ITS) regions were amplified with primer pair 5.8S_Fung/ITS4 targeting the ITS2 region (Taylor et al. 2016).

Raw sequences were submitted to NCBI BioProject database under Project ID PRJNA516816

(http://www.ncbi.nlm.nih.gov/bioproject/516816).

\subsection{Bioinformatics and statistics}

For $16 \mathrm{~S}$ sequences, the base quality of the reads 1 and reads 2 was controlled using the functions fastx_quality_stats and fastq_quality_boxplot_graph of the FASTX-Toolkit (http://hannonlab.cshl.edu/fastx_ toolkit/). PANDAseq (Masella et al. 2012) was used to assemble the read 1 and the read 2 using the RDP algorithm, a minimum and maximum length of the resulting sequence of $410 \mathrm{bp}$ and $500 \mathrm{bp}$, respectively, a minimum and maximum overlap length of $20 \mathrm{bp}$ and $100 \mathrm{bp}$, respectively. The resulting sequences were stripped out from the primers and annotated at the genus or family level by RDP Classifier (Wang et al. 2007) using the RDP 16S rRNA database and an assignment confidence cutoff of 0.6. This signifies that $60 \%$ of K-mers will match at the genus level. Singletons were removed.

For ITS sequences, forward and reverse reads were merged using vsearch (Rognes et al. 2016). Sequences were quality filtered and assembled in QIIME pipeline (Caporaso et al. 2010). Chimeras were removed using UCHIME (Edgar et al. 2011) with closed reference and de-novo approach. OTUs (operational taxonomic units) were assembled at $97 \%$ similarity using vsearch clustering algorithm at default settings (Rognes et al. 2016) and blasted against UNITE 7.2 database
(Kõljalg et al. 2013). Singletons were removed. Fungal OTUs were merged on genus level (i.e., 603 genera) for all analyses apart from alpha diversity, to account for species length polymorphisms in fungal ITS regions below genus level (Gomes et al. 2002).

Negative control bacterial genera resp. fungal OTUs from the kit and the sampling liquid were subtracted for all samples (see online supplementary material Table S10 and Fig. S1 for sequence statistics and rarefaction curves). Statistical analyses were done in $R$ ( $\mathrm{R}$ Core Team 2015) using the phyloseq (McMurdie and Holmes 2013), vegan (Oksanen et al. 2018) and ggplot (Wickham 2009) packages.

The alpha diversity Chao1 richness index $S_{1}$ was calculated as follows:

$S_{1}=S_{\mathrm{obs}}+\frac{F_{1}^{2}}{2 F_{2}}$

where $S_{\text {obs }}$ is the number of species in the sample, $F_{1}$ is the number of singletons, and $F_{2}$ is the number of doubletons.

The alpha diversity Shannon evenness-Index $H^{\prime}$ was calculated as follows:

$H^{\prime}=\sum_{i} p_{i} * \ln p_{i} \operatorname{mit} p_{i}=\frac{n_{i}}{N}$

with $p_{i}$ being the relative abundance of a certain species $i$ of the total number of individuals $N$ and $n_{i}$ being the absolute number of individuals belonging to one species.

The data set was run both rarefied and untreated, which did not show differences in statistical analyses, but removed rare genera. To include otherwise removed genera and to present the data characteristics appropriately, relative abundance analysis was carried out on non-filtered data (Weiss et al. 2017). The fungal dataset was third-root transformed. Bray-Curtis distances for bacteria and fungi were calculated on datasets normalized to relative abundance (Weiss et al. 2017) and ordinated with non-metric multidimensional scaling (NMDS). The samples May_T12, May_5, May_T6 and May_T12 had to be excluded from the ITS analyses, as they had too few reads to calculate NMDS.

Pairwise PERMANOVA was conducted using the package "pairwiseAdonis" (Martinez Arbizu 2017); Bonferroni $p$ value correction was applied as default for multiple corrections. Statistical parameters of ANOSIM (999 permutations), ADONIS (999 
permutations), Kruskal-Wallis, Dunns PostHoc and PERMANOVA analysis are reported in the online supplementary data (Tables S5-S9).

SIMPER (Similarity Percentage), describing the species contribution of Bray-Curtis distance between two groups, was calculated in vegan (supplementary Tables S12-S18).

Obtained air and precipitation samples were blasted (blast version 2.7.1) against a nucleotide database of organisms containing the ice nucleation protein (search for "ice nucleation protein"), created from ncbi (www.ncbi.nlm.nih.gov), with a threshold of $97 \%$ similarity. The obtained reads were filtered for matches longer than 400 base pairs and merged on genus level.

\subsection{Microbial enumeration}

\subsubsection{S rRNA gene qPCR}

The bacterial cell concentration was approximated by the number of 16S rRNA gene copies per cubic meter of air. The V3 region of the 16S rRNA gene was quantified using the Quantifast 2X SYBR Green dye (QIAGEN Venlo, Netherlands) and the following primer sequences: Eub 338f 5'-ACTCCTACGGGAGGCAGCAG- $3^{\prime}$ as the forward primer and Eub 518r 5'-ATTACCGCGGCTGCTGG-3' as the reverse primer (Øvreås and Torsvik 1998) on a Rotor-Gene 3000 machine (QIAGEN, Venlo, Netherlands). The reaction mixture of $20 \mu \mathrm{l}$ contained $10 \mu \mathrm{l}$ of SYBR master mix, $2 \mu 1$ of DNA and RNAse-free water to complete the final $20 \mu \mathrm{l}$ volume. The qPCR two-step program consisted of an initial step at $95{ }^{\circ} \mathrm{C}$ for $2 \mathrm{~min}$ for enzyme activation and then 35 cycles of $5 \mathrm{~s}$ at $95{ }^{\circ} \mathrm{C}$ and $20 \mathrm{~s}$ at $60{ }^{\circ} \mathrm{C}$ hybridization and elongation. A final step was added to obtain a denaturation from $55{ }^{\circ} \mathrm{C}$ to $95{ }^{\circ} \mathrm{C}$ with increments of $1{ }^{\circ} \mathrm{C} \mathrm{s}^{-1}$. The amplicon length was around $200 \mathrm{bp}$. PCR products obtained from DNA from a pure culture of Escherichia coli were cloned in a plasmid (pCRtm2.1-TOPO ${ }^{\circledR-}$ vector, Invitrogen, Carlsbad, USA) and used as a standard quantification with the Broad-Range Qubit Fluorometric Quantification (Thermo Fisher Scientific, Waltham, USA). Non-template controls were subtracted.

\subsubsection{S rRNA gene qPCR}

The fungal cell concentration was approximated by the number of 18S rRNA gene copies per cubic meter of air. The region located at the end of the SSU $18 \mathrm{~S}$ rRNA gene, near the ITS1 region, was quantified using the Quantifast 2X SYBR Green dye (QIAGEN, Venlo, Netherlands) and the following primer sequences: FR1 $5^{\prime}$-AICCATTCAATCGGTAIT- $3^{\prime}$ as the forward primer and FF390 5'-CGATAACGAACGAGACCT-3' as the reverse primer (Chemidlin Prévost-Bouré et al. 2011) on a Rotor-Gene 3000 machine (QIAGEN, Venlo, Netherlands). The reaction mixture of $20 \mu \mathrm{l}$ contained $10 \mu \mathrm{l}$ of SYBR master mix, $2 \mu \mathrm{l}$ of DNA and RNAse-free water to complete the final $20 \mu \mathrm{l}$ volume. The qPCR two-step program consisted of an initial step at $95{ }^{\circ} \mathrm{C}$ for 5 min for enzyme activation and then 35 cycles of $15 \mathrm{~s}$ at $95^{\circ} \mathrm{C}$ and $30 \mathrm{~s}$ at $60{ }^{\circ} \mathrm{C}$ hybridization and elongation. A final step was added to obtain a denaturation from $55^{\circ} \mathrm{C}$ to $95{ }^{\circ} \mathrm{C}$ with increments of $1^{\circ} \mathrm{C} \mathrm{s}^{-1}$. The amplicon length was around $390 \mathrm{bp}$. PCR products obtained from DNA from a soil sample were cloned in a plasmid (pCRtm2.1-TOPO ${ }^{\circledR}$ vector, Invitrogen, Carlsbad, USA) and used as a standard quantification with the BroadRange Qubit Fluorometric Quantification (Thermo Fisher Scientific, Waltham, USA). Non-template controls were subtracted.

\subsection{Meteorology}

Meteorological and aerosol data were obtained from the Sonnblick Observatory repository. An aerosol backscatter profile from VAISALA CL51 ceilometer located at Kolm-Saigurn (the base of Mount Sonnblick at $1500 \mathrm{~m}$ asl.), and PBL heights were obtained from ZAMG (Zentralanstalt für Meteorologie und Geodynamik, Vienna). The mixing layer heights were calculated according to Lotteraner and Piringer (2016) (see online supplementary information Figs. S3-S6). The lagrangian model FLEXPART (Stohl et al. 2002) was used in backward mode to detect the most probable source regions for microorganisms which may have been transported with longrange air flows. The model output fields depict the regions with high source-receptor sensitivity due to the prevailing three-dimensional flow fields predicted by the ECMWF model for 120-h backcalculation (see online supplementary material Fig. S6 for model 
output). Mixing layer height calculation and FLEXPART backward calculation are described in the supplementary information of Els et al. (2019).

\section{Results}

\subsection{Meteorology}

Atmospheric temperatures were lowest during February and highest in August, with highest mean relative humidity in May (compare Table 2, compare Supplement Figure S3 for respective meteorological conditions at each sampling time).

Based on backward dispersion modeling results, air masses originated from different regions during each of the seasonal sampling campaigns (Supplement Figure S6). Samples collected in May were free tropospheric air mainly of maritime origin transported from the Atlantic over France to the Alpine region. Some transport from the Mediterranean region may have influenced the first sample collected on May 2, 2017. In August, the main source regions were identified as the Mediterranean Sea and North Africa and at the end of the sampling period, additional contributions from air masses traveling over Western Europe and the eastern Atlantic were observed. In November, the free tropospheric air was tracked back to the British Island and Iceland, even up to the northern Polar region. The sampling on November 11, 2017, was influenced by air that had been transported over Northern Spain, the Riviera and the Po Valley. In February, the air masses reaching the observatory during the sampling days had been influenced by flow from most of Europe and the Mediterranean area.

In the first days of May 2017, the core of a lowpressure system was centered over the Eastern Alpine region, resulting in cloudy conditions and strong snow fall in the morning of May 2, 2017 as well as in the night of May 4 to 5, 2017. In August, intermittent precipitation was observed during the sampling periods T1, T5 and T13 (Table 1). On August 3 to 6, 2017, a series of frontal passages dominated the meteorological conditions at Sonnblick Observatory. Heavy precipitation, thunderstorms and hail occurred during sampling, and mean wind speeds were lowest as compared to the other measurement periods.

For the period between November 27 and 30, 2017, weak pressure gradients dominated the weather 
conditions in the Alpine area, resulting in low temperatures. In February, no precipitation was observed. While low-pressure gradients prevailed during the first day of this period, a cyclone over the Mediterranean caused an increase in wind speeds up to $14.8 \mathrm{~ms}^{-1}$ at the Sonnblick Observatory on February 21, 2018.

Samples collected in May, November and February were entirely in the free troposphere (Supplement Figure S4). A deep convective boundary layer reached above the mountain top on August 3 and 4, 2017, and the mixing heights determined from the ceilometer measurements indicated that the boundary layer air remained below the observatory on August 5 and 6, 2017.

Stable stratification of the valley boundary layer, characterized by low mixing heights, prevented significant transport of valley air to the mountain top in February and November. Mixing heights were low during these periods, most of the time below $400 \mathrm{~m}$ AGL (compare Supplement Figures S4 and S5).

\subsection{Seasonality of bacterial and fungal communities}

\subsubsection{Abundance}

The median of 16S rRNA gene abundance per $\mathrm{m}^{3}$ air was highest in November $\left(1.14 \times 10^{6} \mathrm{~m}^{-3}\right.$ air $)$ and lowest in February $\left(2.67 \times 10^{5} \mathrm{~m}^{-3}\right.$ air $)$, with the biggest range (Coefficient of Variation CV: 2.47) and highest $\left(1.67 \times 10^{7} \mathrm{~m}^{-3}\right.$ air $)$ and lowest values $\left(1.18 \times 10^{5} \mathrm{~m}^{-3}\right.$ air $)$ in May. The smallest variation coefficient was found in August (0.58). Dunn pairwise comparison revealed significant difference for all groups except between May and February $(p=0.054)$ and May and August $(p=0.44)$ (Fig. 2a).

The highest median and absolute maximum, but lowest variation of $18 \mathrm{~S}$ rRNA gene abundance per $\mathrm{m}^{3}$ air was found in November (median: $5.1 \times$ $10^{4} \mathrm{~m}^{-3}$ air, max: $9.98 \times 10^{4} \mathrm{~m}^{-3}$ air, CV: 0.65 ), the lowest median and absolute value, but highest variation in May (median: $1.0 \times 10^{2} \mathrm{~m}^{-3}$ air, min: $6.13 \times 10^{0} \mathrm{~m}^{-3}$ air, CV: 2.45 ). Dunns pairwise comparison revealed significant difference between all groups but February and August ( $p=0.069$ ) (Fig. 2a).

The lowest median of the $16 \mathrm{~S}$ to $18 \mathrm{~S}$ rRNA gene ratio was found in November $\left(3.86 \times 10^{1} 16 \mathrm{~S}: 18 \mathrm{~S}\right.$ $\mathrm{m}^{-3}$ air). May had the highest median ratio $\left(4.02 \times 10^{3} 16 \mathrm{~S}: 18 \mathrm{~S} \mathrm{~m}^{-3}\right.$ air $)$ and maximum value $\left(2.28 \times 10^{5} 16 \mathrm{~S}: 18 \mathrm{~S} \mathrm{~m}^{-3}\right.$ air $)$, but also highest variation (2.31). The lowest ratio and variation coefficient was found in August $\left(9.74 \times 10^{0} 16 \mathrm{~S}: 18 \mathrm{~m}^{-3}\right.$ air, CV: 0.72). Dunns pairwise comparison revealed significant differences between all but August and February ( $p=0.14$ ) (Fig. 2a). The seasonal abundance of $16 \mathrm{~S}$ rRNA genes, 18S rRNA genes and their ratio was significantly different (Kruskal-Wallis $p<0.001$ ).

\subsubsection{Alpha diversity}

Bacterial and fungal read counts per sample ranged from 13478 to 41882 and 568 to 34638, respectively, after quality filtering. The whole dataset comprised 1590 bacterial genera and 2573 fungal OTUs, which accounted for 963 bacterial genera and 1912 fungal OTUs (resp. 603 fungal genera) after removal of blanks.

The overall median and mean of bacterial Chao1 (describing richness, Fig. 2b) were 48, with the lowest median in August (40.75) and the highest in November (70.06), and the lowest value in August (19.33) and the highest in February (160.00). November differed significantly from May $(p=0.023)$ and August $(p=0.0368)$, whereas in February significant differences to August were detected ( $p=0.0368$, KruskalWallis $p=0.03)$. The highest variation was found in May (0.61) and the lowest in November (0.34).

The overall median of Shannon (describing evenness, Fig. 2b) alpha diversity index for bacteria was 2.37 and the mean 2.31, ranging from 1.99 (February) to 2.61 (May). The lowest value was found in November (0.25) and the highest in May (3.26). Variation was highest in November (0.39) and lowest in August (0.11). Shannon diversity differed significantly in February from all other months (Feb-May $p=0.0006$, Feb-Aug $p=0.0008$, Feb-Nov $p=$ 0.0247, Kruskal-Wallis $p<0.001)$.

The highest fungal richness (median (48.5) and maximum value (81)) was observed in August, while the lowest value was recorded for May (median (3) and absolute value (1), variability (0.36)). Variability was highest in February (0.81). All values were significantly different from each other (KruskalWallis $p<0.001$ ) apart from November and February (Dunns $p=0.3053$ ).

The highest fungal evenness (Shannon) median (2.89) and absolute value (3.65) was recorded in 
Fig. 2 a Abundance of $16 \mathrm{~S}, 18 \mathrm{~S}$ and $16 \mathrm{~S}$ to $18 \mathrm{~S}$ ratio $\mathrm{m}^{-3}$ air per season, b alpha diversity measures Chaol and Shannon for bacteria and fungi

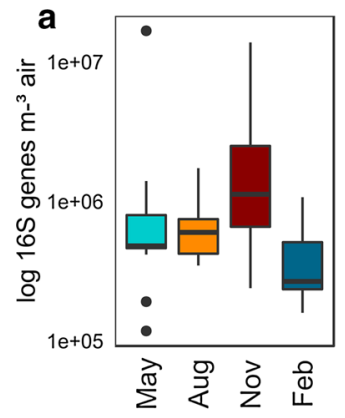

b

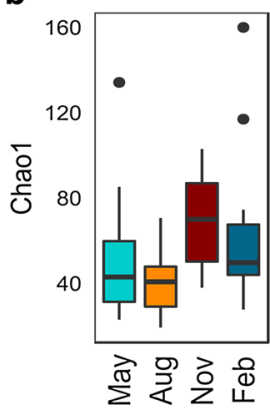

Bacteria

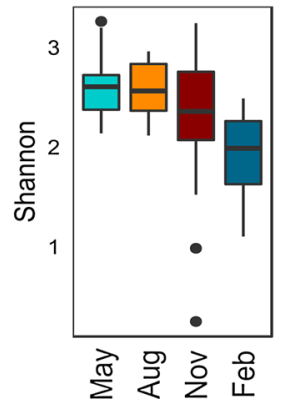

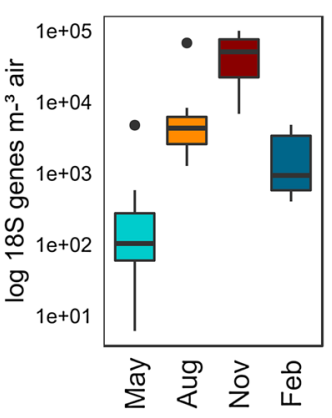

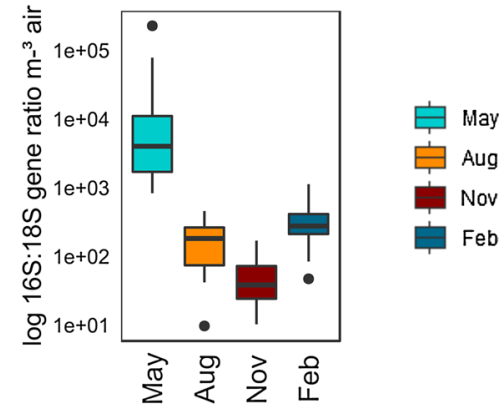

Fungi
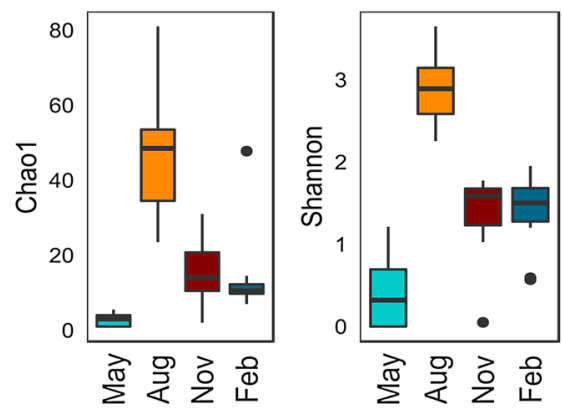

August, and the lowest median occurred in May (0.32) and in November (0.05).

November and February did not differ significantly ( $p=0.4647)$, but all other groups did (Kruskal-Wallis $p<0.001)$. Variability was highest in May (1.10) and lowest in August (0.15).

\subsubsection{Beta diversity}

Seasonal air bacterial communities were significantly different (ADONIS $p=0.001, R^{2}=0.166$, ANOSIM $p=0.001, R=0.114)$. They differed significantly between February and May (PERMANOVA adj. $p=$ 0.006), February and August (PERMANOVA adj. $p=$ 0.006), May and November (PERMANOVA adj. $p=$ 0.006) and August and November (PERMANOVA adj. $p=0.006)$. February samples were the most variable and distinct as compared to the other communities. The February and November (winter) and May and August (summer) bacterial communities did not differ significantly. On phylum level, winter samples were most abundant in Firmicutes (Nov: 78.4\%, Feb: $48.1 \%$ ), whereas summer samples were abundant in Proteobacteria (May: 54.3\%, Aug 49.4\%), Bacteroidetes, Acidobacteria and Planctomycetes (Fig. 3c).

The highest value of unique air bacterial genera was reached in May, the lowest in August.
61 genera, i.e., $11 \%$ of the total bacterial genera, were common to all seasons (Fig. 3b). The most abundant of these common bacteria belonged to the genera Geobacillus (Bacilli), Aminobacter (Alphaproteobacteria) and Schlesneria (Planctomycetia) (see online supplement Tables S1 and S2).

Of all bacterial air genera, $54 \%$ were unique to one of the seasons. The most abundant genera only occurring in May and August were GP2 (Acidobacteria), Domibacillus (Bacilli) and Paludibacter (Bacteroidia). Most abundant unique genera in winter samples were Bifidobacterium (Actinobacterium), Vulcaniibacterium (Gammaproteobacteria) and $\mathrm{Po}$ laribacter (Flavobacteria). SIMPER analysis (see supplement Tables S12 and S13) revealed Geobacillus abundance in February and November as the driver of differences between summer and winter samples. Further, high abundances in Microbacterium, Tumebacillus in winter and presence of Aminobacter, Bosea, Burkholderia and Schlesneria in summer differentiated samples.

Air fungal seasonal communities also significantly differed (ADONIS $p=0.001, R^{2}=0.3075$, ANOSIM $p=0.001, R=0.5225)$. All seasons differed from each other (PERMANOVA $p$.adj $=0.006$, respectively); however, NMDS of Bray-Curtis distance (Fig. 3a) revealed that May samples were most dispersed, while August samples were most similar 
and February and November samples had the highest overlap.

August samples were dominated Agaricomycetes, Lecarnomycetes and Leotiomycetes, while May fungal communities were characterized by Eurotiomycetes, Saccharomycetes, Tremellomycetes and Wallemiomycetes. Winter samples had a high amount of unidentified organisms, November was characterized by high abundance in Sordarimycetes (23.2\%) and Tremellomycetes (12.1\%), while February featured many Agaricomycetes (34.6\%).

Only $3 \%$ of the identified fungal air genera were common in all seasons. The most abundant were unidentified Ascomycota, unidentified Agaricomycetes, Formitopsis (Agaricomycetes), Aspergillus (Eurotiomycetes) and Trichaptum (Agaricomycetes). The highest share of unique genera was found in August (53.9\% of all identified fungal genera), with Teloschistaceae (Lecarnomycetes), Gymnopus (Agaricomycetes) and Resupinatus (Agaricomycetes) and range of Agaricomycetes identified as the most abundant. February contained the second most fungal genera detected in air (31.7\% of all fungal genera detected), with Exidia (Agaricomycetes), Talaromycetes (Eurotiomycetes) and Taphrina (Taphrinomycetes) as most abundant unique genera (supplementary. Table S2). SIMPER analysis (supplement Table S16) revealed Phanerochaete, Formitopsis, Aspergillus and Wallemia as driving fungal genera distinguishing May samples from all other seasons. August had characteristically high abundances of Sacrogyne, Acarospora and Formitopsis, while Mycena, Saccharomyces, Extremus were characteristic in February, and Exophilia, Filobasidium for November.

\subsection{Abundance and diversity of bacterial and fungal communities in air and precipitation}

\subsubsection{Comparison of abundance in air and precipitation}

The median of $16 \mathrm{~S}$ rRNA gene abundance $\mathrm{m}^{-3}$ air $\left(5.23 \times 10^{5}\right)$ is within one order of magnitude of the abundance per $\mathrm{mL}$ cloud $\left(1.17 \times 10^{5} \mathrm{~mL}^{-1}\right)$ or snow $\left(2.66 \times 10^{5} \mathrm{~mL}^{-1}\right)$. Rain water $\left(2.29 \times 10^{7} \mathrm{~mL}^{-1}\right)$ and hail $\left(1.88 \times 10^{7} \mathrm{~mL}^{-1}\right)$ showed two orders of magnitude higher values (Fig. 4).
Minimum values of $16 \mathrm{~S}$ rRNA genes $\mathrm{mL}^{-1}$ in precipitation were reached in snow $\left(1.87 \times 10^{2} \mathrm{~mL}^{-1}\right)$; maximal concentration of $16 \mathrm{~S}$ rRNA genes was present in rain $\left(4.28 \times 10^{7} \mathrm{~mL}^{-1}\right)$. Variation was lowest in cloud (0.94) and higher in snow (1.67), but highest in air (2.18).

Air and precipitation 16S rRNA gene abundances were significantly different (Kruskal-Wallis $p=0.001)$, with cloud and air (p.adj. =0.0012) and cloud and rain $(p$. adj. $=0.0004)$ differing strongly. Further hail vs. rain and snow vs. air, cloud, hail and rain differed in unadjusted testing.

The median of $18 \mathrm{~S}$ rRNA gene abundance $\mathrm{m}^{-3}$ air $\left(3.01 \times 10^{3} \mathrm{~m}^{-3}\right.$ air $)$ was lower than in cloud $\left(8.55 \times 10^{4} \mathrm{~mL}^{-1}\right)$ and snow $\left(2.02 \times 10^{4} \mathrm{~mL}^{-1}\right)$, much higher in hail $\left(1.46 \times 10^{7} \mathrm{~mL}^{-1}\right)$ and lower in rain $\left(7.72 \times 10^{2} \mathrm{~mL}^{-1}\right)$.

$16 \mathrm{~S}$ to $18 \mathrm{~S}$ ratio (Kruskal-Wallis $p<0.001$ ) differed in air and cloud ( $p$.adj $=0.0001)$, snow and air (p.adj. =0.0002), and rain and snow (p.adj. = $0.0161)$. The highest median $16 \mathrm{~S}: 18 \mathrm{~S}$ ratio occurred in rain $\left(3.18 \times 10^{4}\right)$, and a higher $16 \mathrm{~S}: 18 \mathrm{~S}$ ratio in air $\left(2.29 \times 10^{2}\right)$ than in cloud $\left(1.15 \times 10^{0}\right)$, snow $\left(2.81 \times 10^{1}\right)$ and hail.

$18 \mathrm{~S}$ rRNA gene abundance in precipitation (Kruskal-Wallis $p=0.01$ ) differed only in snow and air ( .adj. $=0.0375$ ), but further in air and cloud, cloud and rain, hail and rain and rain and snow in unadjusted testing (supplement Tables S5, S8, S9).

\subsubsection{Alpha diversity in air and precipitation}

Chao1 for bacteria differed in air and cloud ( $p$.adj. = 0.0027), air and snow (p.adj. $=0.0000)$, rain and snow ( .adj. $=0.0038$ ) and cloud and rain ( .adj. $=$ $0.0254)$ as well as overall (Kruskal-Wallis $p<0.001)$.

Bacterial Shannon evenness (Kruskal-Wallis $p<0.001)$ differed in air and cloud ( $p$.adj. $=0.0535)$, air and snow (p.adj. $=0.0000)$, hail and snow (p.adj. =0.0464).

Fungal Chao1 (Kruskal-Wallis $p<0.001$ ) differed in cloud and air ( $p$.adj. $=0.0000)$ and air and snow ( .adj. $=0.0000)$, further in cloud and rain, hail and rain and rain and snow in unadjusted testing. Fungal Shannon (Kruskal-Wallis $p<0.001$ ) differed as well in air and cloud ( $p$. adj. $=0.0090)$ and snow and air ( $p$.adj. $=0.0001)$ and further in rain and cloud and rain and snow in unadjusted testing. 

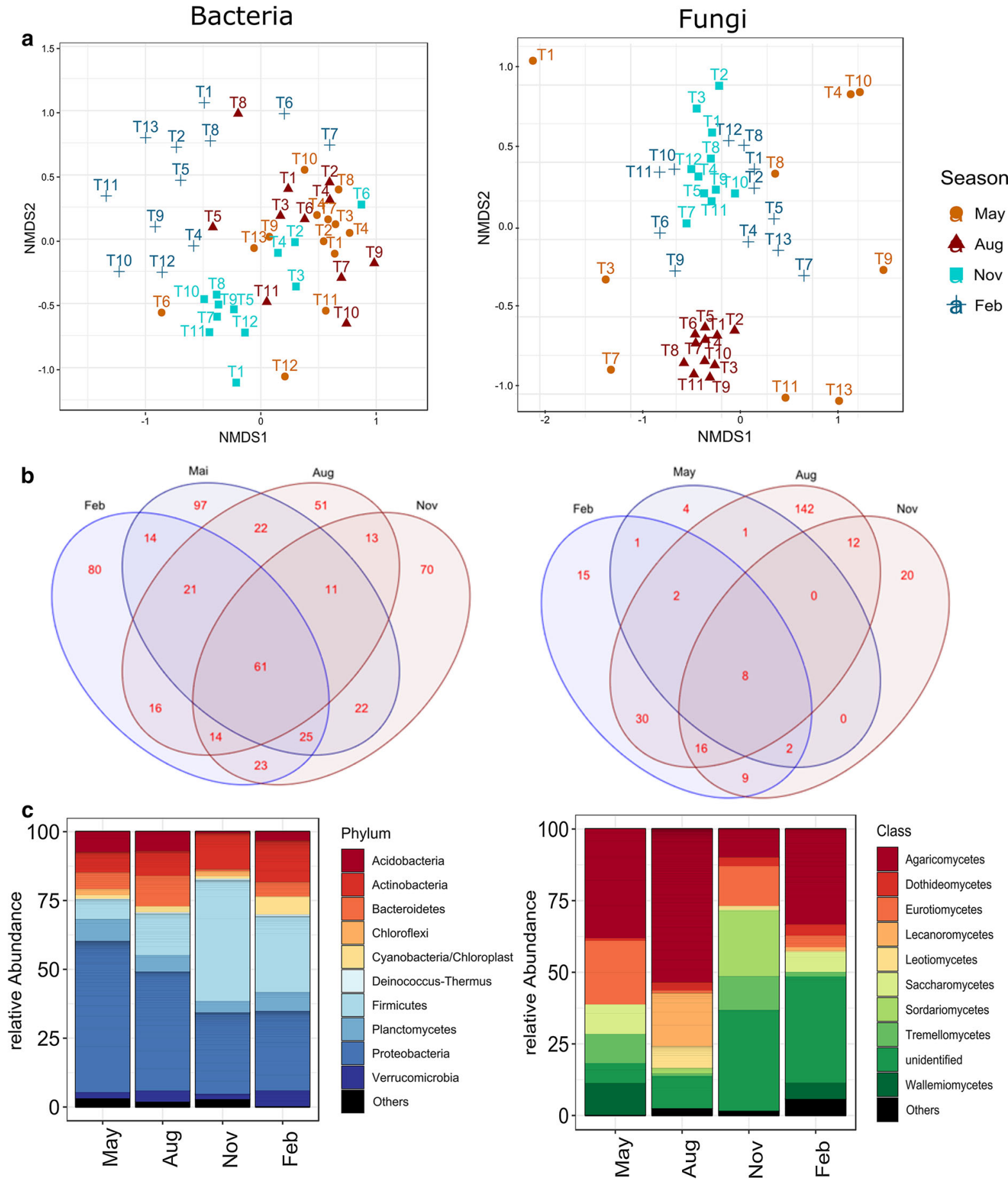

Fig. 3 a NMDS on Bray-Curtis distance on genus for bacteria and fungi for air composition by season, b Venn diagram of unique and common bacterial and fungal genera by season, $\mathbf{c}$ relative abundance (\%) of top 10 most abundant bacterial phyla and fungal classes 

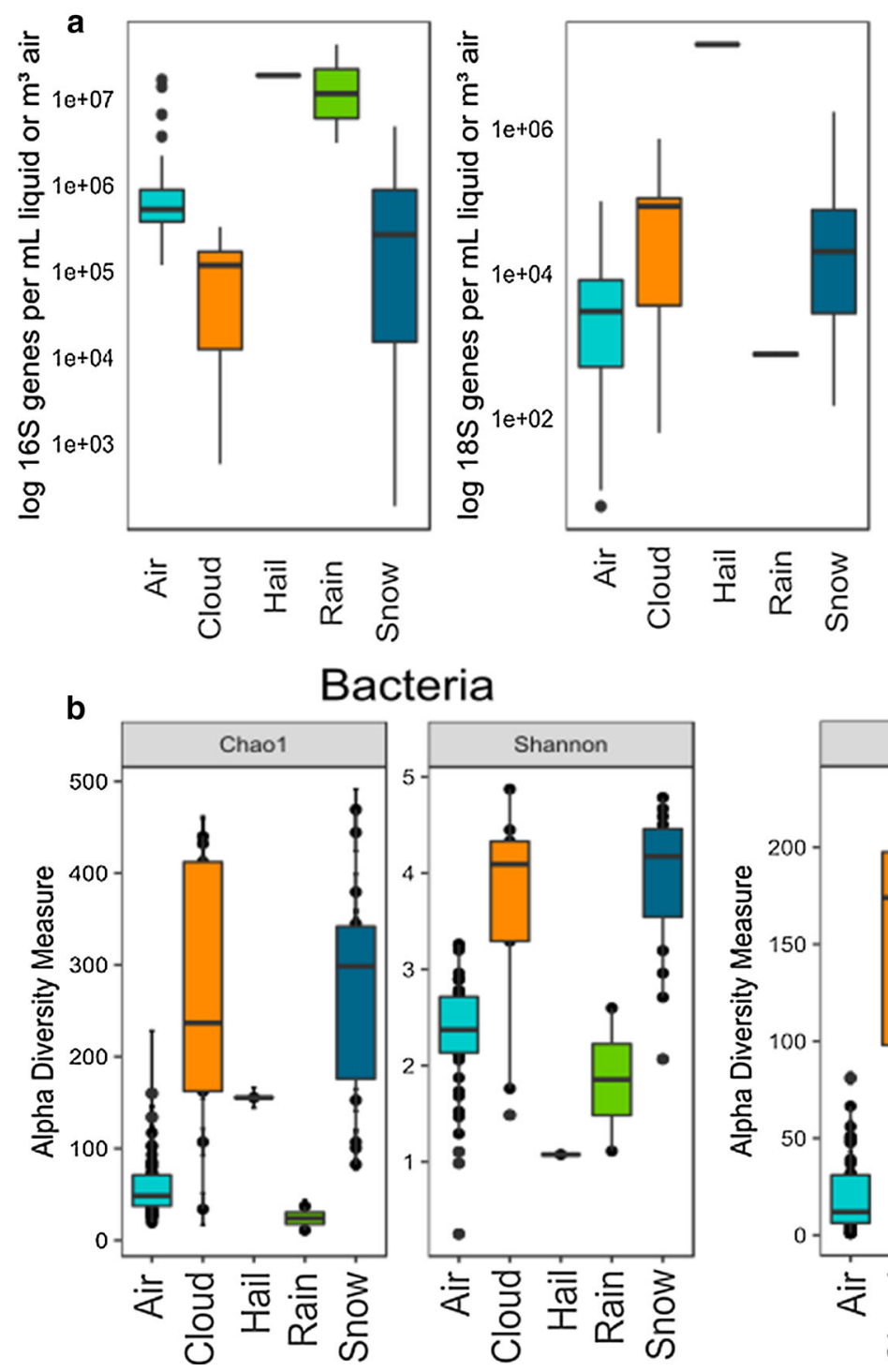

Fig. 4 a 16S rRNA genes, 18S rRNA genes and 16S:18S ratio $\mathrm{m}^{-3}$ air and $\mathrm{mL}^{-1}$ precipitation, $\mathbf{b}$ alpha diversity indices in air and precipitation for bacteria and fungi

\subsubsection{Beta Diversity in air and precipitation}

NMDS (Fig. 5a) revealed a strong clustering of bacterial communities of precipitation, with rain and one May cloud sample being most distinct. The February bacterial air samples are the most distinct from precipitation.

August fungal samples cluster closest together in air samples and closest to precipitation. Fungal precipitation samples cluster more densely than any season for air, apart from August rain samples and one May cloud sample, which are more distinct. Fungal
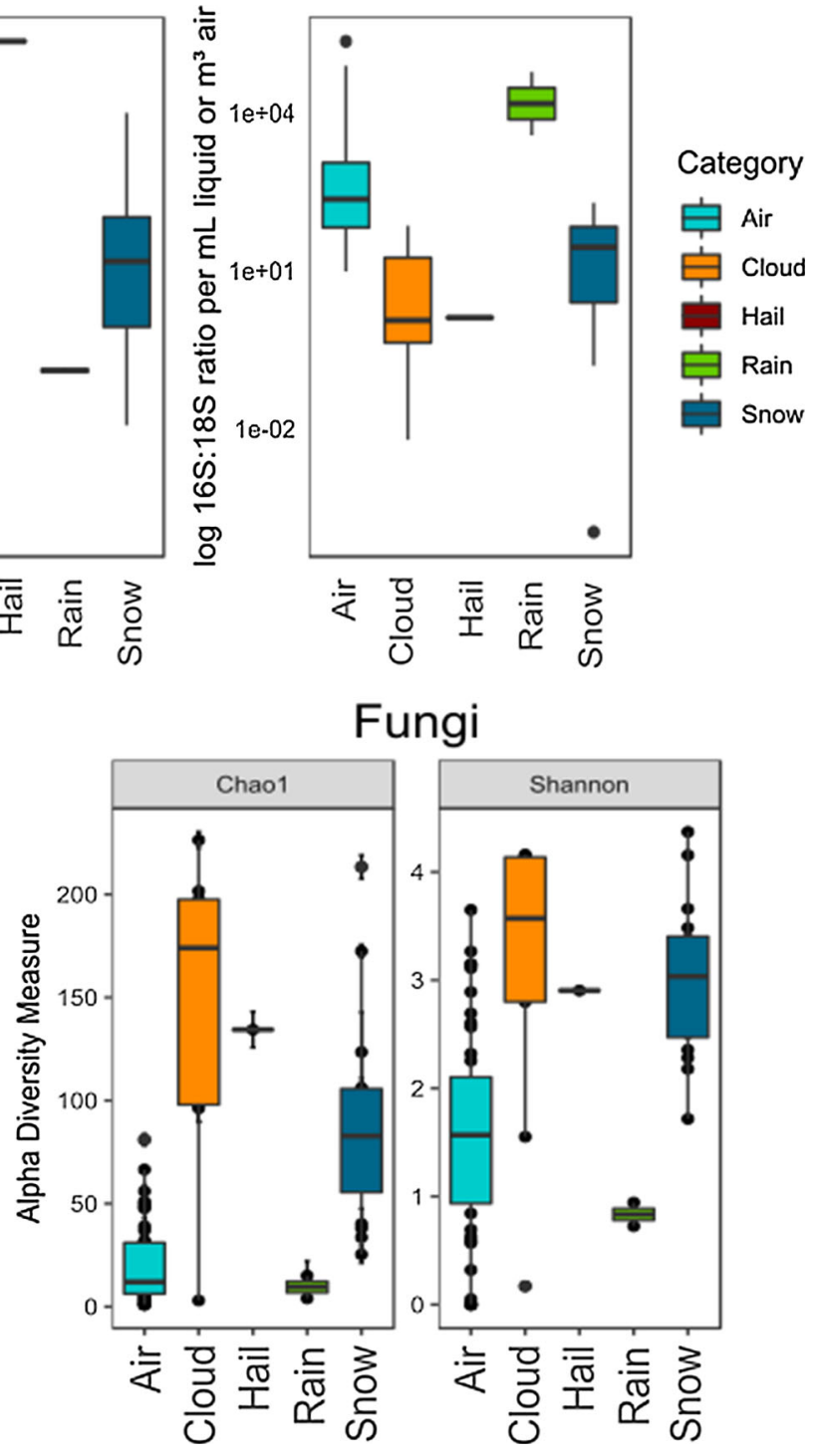

Fungi 
Also fungal air communities differed significantly from precipitation (ADONIS $R^{2}=0.1076, p=0.008$, ANOSIM $R=0.0697, p=0.001$ ). Air and snow resp. cloud fungal communities differed significantly (airsnow, air-cloud: PERMANOVA $p$.adj $=0.01$ ). Fungi in air and rain differed in single testing (PERMANOVA unadj. $p=0.046$, adj. $p=0.46$ ). Snow and rain fungi were significantly different (PERMANOVA $\operatorname{adj} . p=0.04)$.

When compared pairwise for each season, bacteria in air were most similar to snow, rain and hail in August (PERMANOVA air-snow $p$ adj. $=0.096$, airrain $p$ adj. $=0.156$, air-hail $p$ adj. $=0.552)$ and snow and cloud in May (PERMANOVA air-snow $p$ adj. $=0.054$, air-cloud $p$ adj. $=0.048)$. Cloud, snow, rain and hail were never significantly different, when compared against each other within one season. In the total dataset, rain and snow showed the biggest difference (PERMAOVA $p$ non-adj. $=0.025)$.

Snow and cloud in cold seasons (November and February) appear similar in bacterial composition, with Acidobacteria (3.2-6.2\%), Actinobacteria (18.6-40.7\%), Bacteriodetes (5.5-22.0\%) and Cyanobacteria (13.4-20.8\%) being abundant, whereas air is dominated by Firmicutes (48.1\%- 78.4\%). Proteobacteria make up a comparable share in air, cloud and snow in winter (11.2-27.2\%). In May, air and cloud are more similar with high abundances in Proteobacteria (54.3\% in air, $51.1 \%$ in cloud), while May snow features high abundances of Actinobacteria (53.8\%) and Firmicutes (19.0\%), while cloud and snow in May feature Cyanobacteria $7.8 \%$ in snow, $8.6 \%$ in cloud) that are very low in May air $(0.9 \%$, Fig. 6).

Air in August features also high numbers of Proteobacteria $(49.4 \%)$ that are even higher in hail $(88.8 \%)$. August snow is dominated by Bacteriodetes (47.4\%), Proteobacteria $(27.1 \%)$ and Actinobacteria (20.1\%), with Firmicutes lacking, and the lowest abundances of Planctomycetes $(0.6 \%)$, Chloroflexi $(0.01 \%)$ and Cyanobacteria $(2.7 \%)$ compared to snow from the other seasons.

Fungi show a similar pattern, with rain and snow being most different in the overall dataset (PERMANOVA $p$.adj. $=0.04)$ and precipitation never significantly differing within season comparison. Highest similarity occurred between air and snow in May (PERMANOVA $p$ adj. $=1.0$ ), but also all precipitations in August and did not differ significantly to air
(PERMANOVA snow $p$ adj. $=0.102$, rain $p$ adj. $=0.066$, hail $p$ adj. $=0.468$ ). Further, air and cloud in February were only significantly different in unadjusted testing (PERMANOVA $p$ non-adj. = $0.028, p$ adj. $=0.084)$.

In fungi, the composition of cloud and snow is similar in winter samples, but different to air. In November, air is dominated by unidentified (35.5\%), Sordariomycetes $(23.2 \%)$ and Eurotiomycetes (14.1\%). In February, air is dominated by Agaricomycetes $(34.6 \%)$ and unidentified $(39.9 \%)$. Clouds and snow in winter were dominated by Leotiomycetes (9.8\% cloud, $16.8 \%$ snow) and Agaricomycetes in November $(27.4 \%$ snow, $26.2 \%$ cloud), Dothideomycetes $\quad(9.9-35.8 \%), \quad$ Eurotiomycetes (15.8-23.9\%), Lecarnomycetes (9.2-26.5\%), further unidentified (9.4-26.8\%, Fig. 6).

In May, air featured in Wallemiomycetes $(11.1 \%)$ and Saccharomycetes (10.4) that rarely occurred in any other air or precipitation sample and May cloud samples featured Tremellomycetes (36.4\%) and Dothideomycetes $(9.8 \%)$.

Snow in both summer samples was high in unidentified organisms. Rain and air featured high abundance of Agariomycetes (59.9\% in air, 55.5\% in rain) in August. Rain was further rich in Sordariomycetes (37.2\%), while hail was abundant in Dothideomycetes $(36.5 \%)$ and Leotiomycetes $(31.6 \%)$.

$11.8 \%$ of bacterial genera and $9.7 \%$ of fungal genera were only found in the $288 \mathrm{~m}^{3}$ of sampled air and not in any of the precipitation samples (Fig. 5b). The share of common bacterial genera (12.4\%) and fungal genera $(11.6 \%)$ was similar. The ratios of unique and common bacterial and fungal genera between precipitation types display a comparable picture, with the biggest \%-differences in shared genera between cloud, snow and air in bacteria $(21.7 \%)$ compared to $13.3 \%$ in fungal genera, unique cloud fungi (15\%) compared to unique cloud bacteria (9.1\%), and bacteria shared between cloud and snow (18.2\%) compared to fungi in cloud and snow (21.5\%).

Most abundant in all sample types were Geobacillus (Firmicutes), Aminobacter (Proteobacteria) and Herpetrichiellaceae (Eurotiomycetes), Fomitopsis (Agaricomycetes) and

Hypholoma (Agaricomycetes) (Supplementary Tables S3 and S4). 

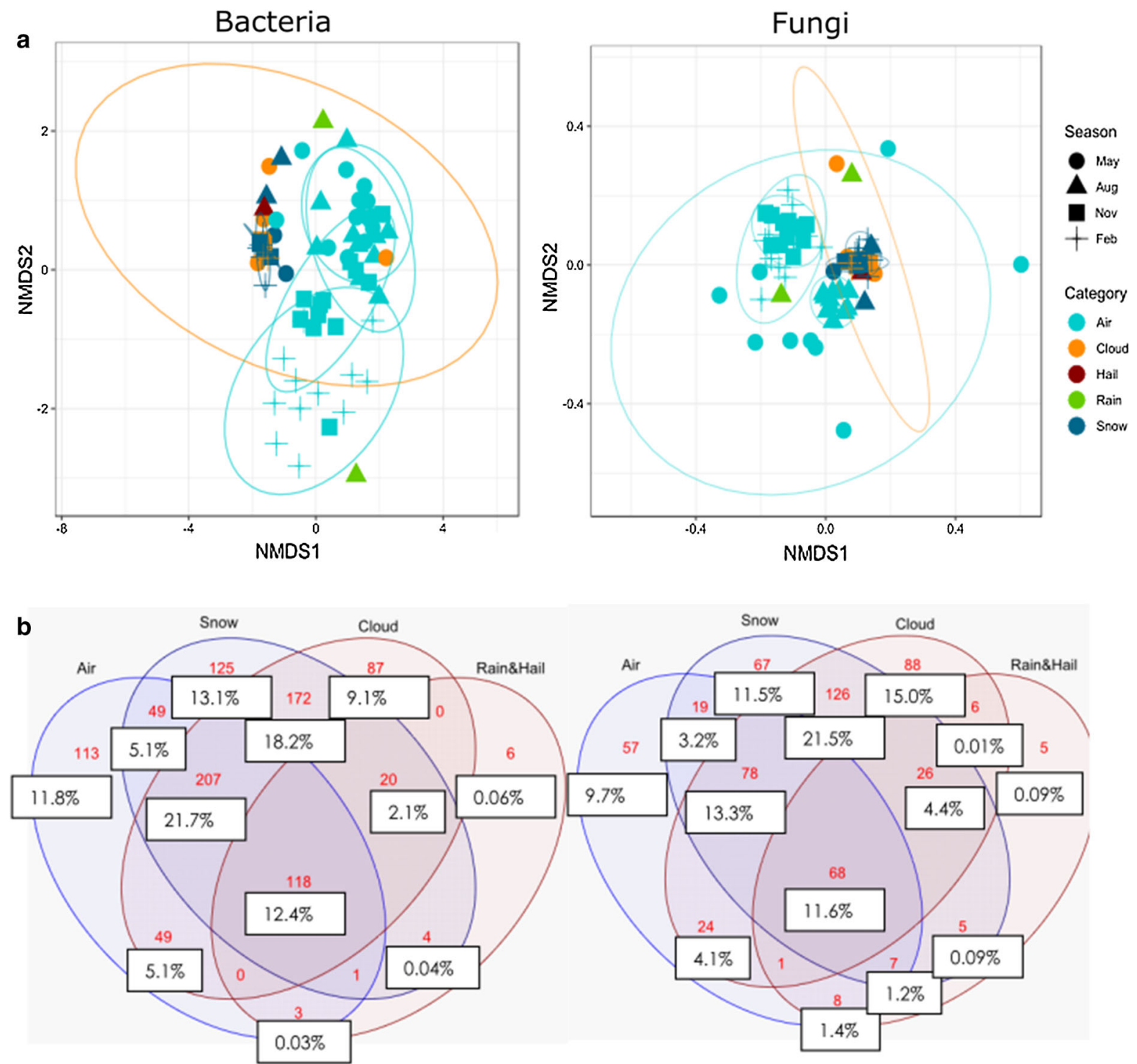

Fig. 5 a NMDS of Bray-Curtis distance of air and precipitation, b Venn diagram of common and unique bacterial and fungal genera

SIMPER analysis (supp Tables S1, S14, S15, S17, S18) revealed that the genera mostly driving differences between air and snow are Geobacillus and Aminobacter that are more abundant in air, and Chlorophyta, Nakamurella and Ferruginibacter that are more abundant in snow, on phylum level Firmicutes were dominant in air compared to Actinobacteria, Bacteriodetes and Cyanobacteria in snow.

The difference between cloud and air was driven by Geobacilli, Bosea and Aminobacter that were more abundant in air and Janthinobacterium and Chlorophyta that were more abundant in clouds, on phylum level Firmicutes were much more abundant in air, whereas Actinobacteria and Cyanobacteria were more abundant in clouds.

In rain, Gpl and Dehalospirillum, Nakamurella and Aquisphaera were more abundant than in air, and Actinobacteria and Acidobacteria were more abundant at the phylum level in rain than in the air.

In hail, Janthiobacterium, Cytophagales and Subtercola drove differences with air, and Proteobacteria was the dominant phylum as compared to Firmicutes, Actinobacteria and Planctomycetes for air samples. 
Fig. 6 Top 10 a bacterial phyla and $\mathbf{b}$ fungal classes for air and precipitation by season
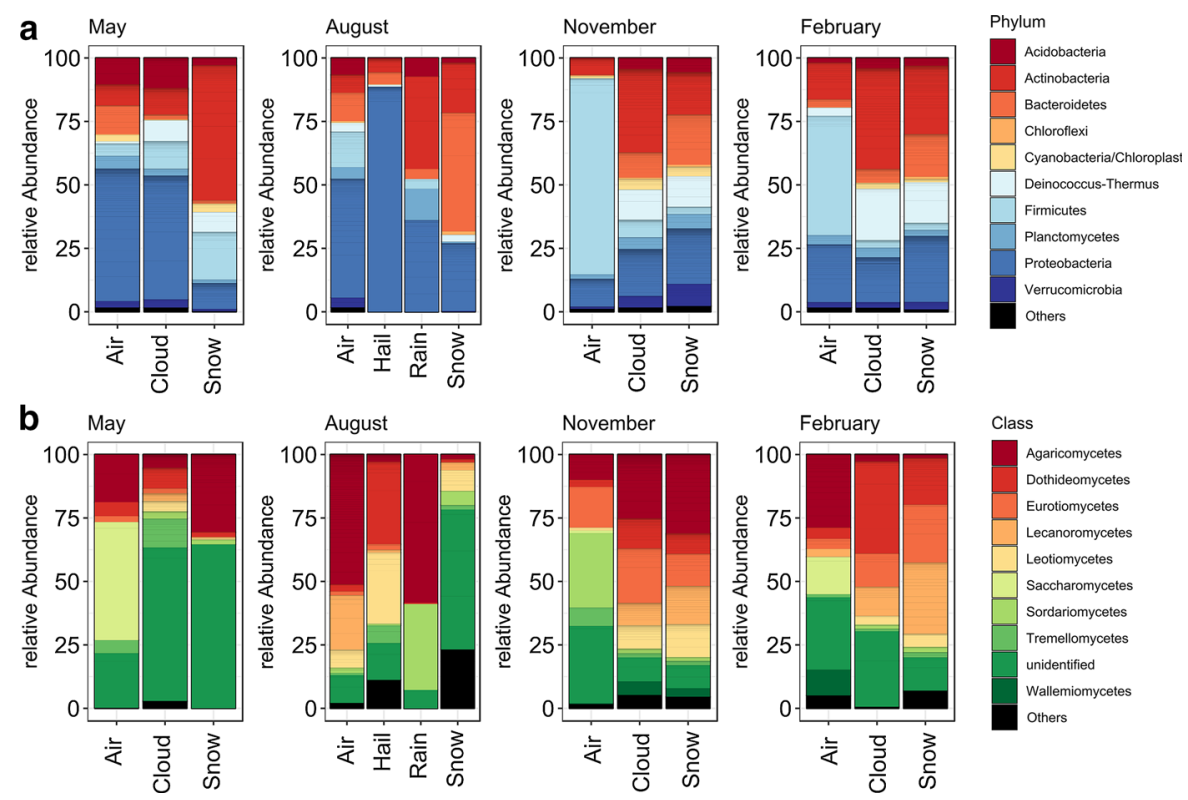

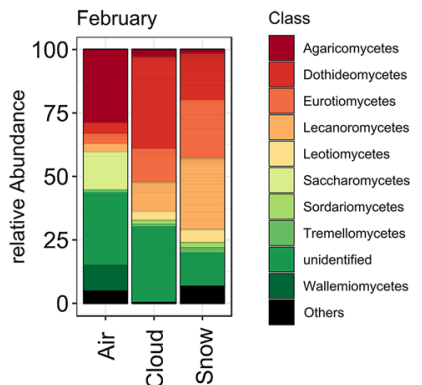

Most abundant unique fungal genera in air were Stereaceae (Agaricomycetes), Curvularia (Dothideomycetes) and Corticium (Agaricomycetes), while most abundant unique genera in snow comprised Phaeosclera (Dothideomycetes) Lactiflus (Agaricomycetes) and Phaerophyscia (Lecarnomycetes), and Phaeomycocentrospora (Dothideomycetes), Byssoloma (Lecarnomycetes) and Rhodosporidiobolus (Microbotryomycetes) in clouds.

For fungi, SIMPER analysis was conducted on class level, as too many unidentified taxa occurred on lower levels. Agaricomycetes were abundant in air compared to snow and cloud, whereas Eurotiomycetes and Dothideomycetes were more abundant in snow and cloud. Lecarnomycetes in snow and Tremellomycetes in cloud also drove differences with air.

Agaricomycetes and Sordariomycetes were more abundant in rain than in air, while Eurotiomycetes, Tremellomycetes and Lecarnomycetes drove the difference of air to rain. In hail, the biggest difference to air was dominated by the presence of Agaricomycetes, Eurotiomycetes and Sordariomycetes in air together with Dothideomycetes, Leotiomycetes and Arthoniomycetes in hail.

\subsection{Ice nucleation-active bacteria}

In total, there were 53 genera containing the ice nucleation protein (INP) detected in the dataset. In air samples, the relative abundance of INP reads of the total reads per sample was lowest in November $(1.56 \%)$ and highest in August (5.28\%), but with high variation. In clouds, relative abundance of IN varied strongly between seasons displaying the highest value in the dataset (15.82\%), whereas in May accounted for only $2.25 \%$ and in February $4.16 \%$. In snow the mean IN abundance varied between $5.22 \%$ in May and $11.51 \%$ in August. Hail ranged at $7.04 \%$ and rain between 0 and $11 \%$ (Fig. 7a). The composition relative abundance of the most abundant INP-containing bacteria showed a similar pattern than the composition of most abundant phyla (discussed in Chapter 3.3, Fig. 6), with snow and cloud being similar in February and November, and more similarity of air and cloud in May, and high variability in August. (Fig. 7b)

NMDS (Fig. 8a) reveals that cloud and air have a higher overlap, than snow and air, with cloud at the interface between air and snow. The two rain samples are different in IN-composition. Hail clusters with snow and cloud. Most of the 53 identified genera containing the ice nucleation protein, present in the dataset, were associated with snow. The occurrence of ice nucleation-active reads is more similar in the frozen water samples (hail, snow) to the clouds, than air. However, the Venn diagram (Fig. 8b) reveals, that the most genera are shared between all of the samples 
or air, snow and cloud, but by NMDS, indicating, that they are more abundant in snow and cloud.

The genera associated with higher abundance in air were Corynebacterium, Pantoea, Enterobacteria, Micrococcus, Caulobacter, Paenibacillus, Acidovorax. Xanthomonas and Erwinia were unique to air.

\section{Discussion}

\subsection{Seasonal differences in air community composition}

Seasonal variation and temporal vicinity of sample composition have been observed for near-surface airborne bacterial and fungal communities (Bowers et al. 2013; Fahlgren et al. 2010; Franzetti et al. 2011; Pickersgill et al. 2017), and even above PBL for bacteria (Bowers et al. 2012). These observations are consistent with our data, which showed that there was no stable free troposphere air microbial community during the year of sampling at Mount Sonnblick, although a core microbiome could be identified consisting of 61 (11\% of all air genera) bacterial and 8 fungal genera (3\% of all fungal air genera). Many of these have previously been identified as indicator species for above PBL air compared to below PBL air (Els et al. 2019). Air mass origin was different for the four sampling periods. Differential source regions and transport have been shown to influence microbial composition of the atmosphere (DeLeon-Rodriguez et al. 2013; Innocente et al. 2017). Zweifel et al. (2012) also suggested annual variation, succession of species in airborne communities or random variation as explanatory mechanisms. One mechanism that might impact microbial composition in air communities is thermal convection and air mass mixing in the boundary layer. The lowest amount of unique bacterial genera was found in August, but the highest number of unique genera was found in May. In August the thermal convection and mixing was most active, with the highest mean boundary layer elevation and variation of the sampling dates (748 $\pm 667 \mathrm{~m} \mathrm{AGL})$. The height of PBL-mixing even reached up to the observatory for a short moment (between T3 and T4, compare supplement data Fig. S4), thus it is likely that
Fig. 7 a Relative abundance (\%) of IN-active bacteria of the total number of $16 \mathrm{~S}$ reads, $\mathbf{b}$ relative abundance of 10 most abundant IN-active genera
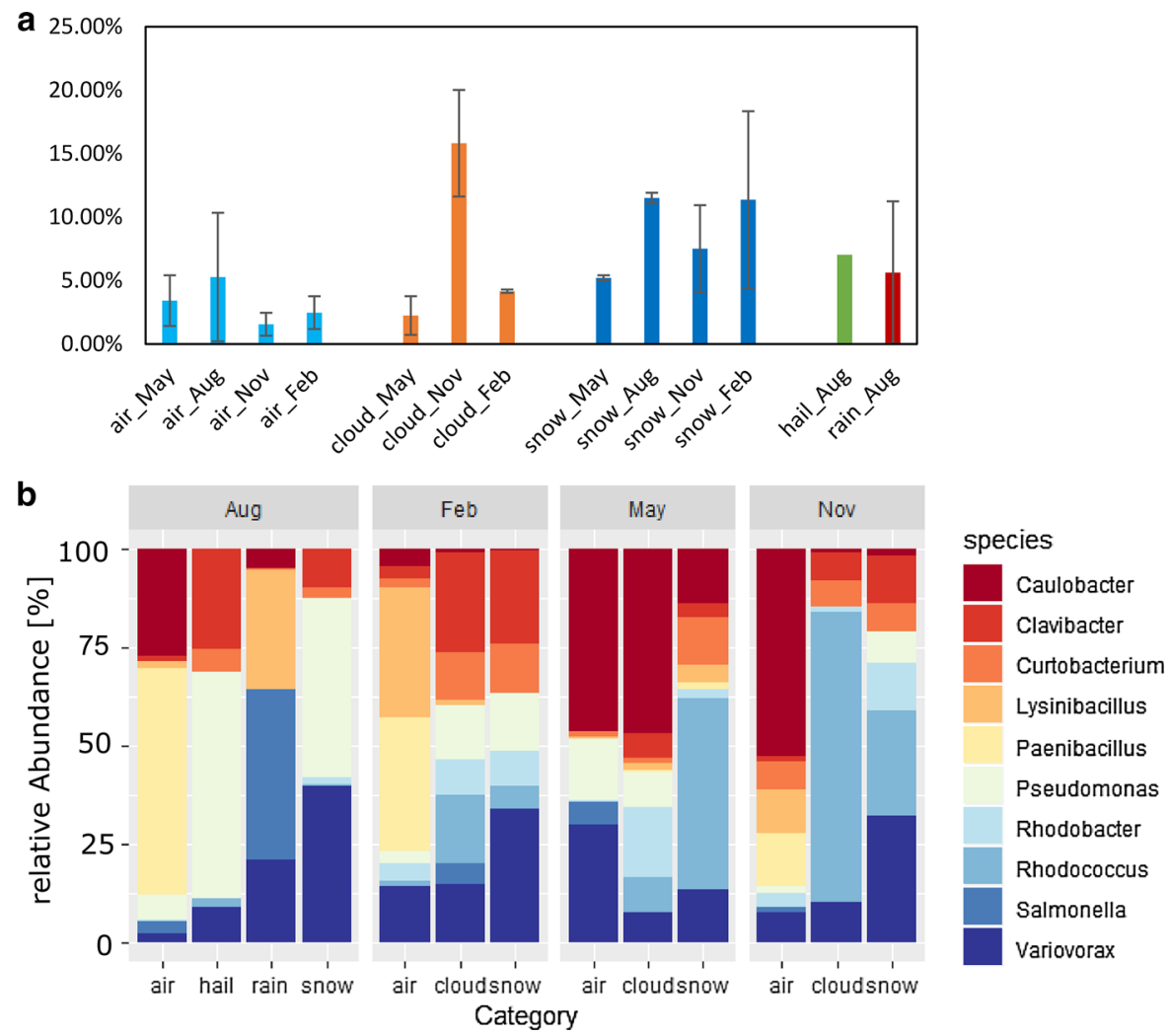
Fig. 8 a NMDS on BrayCurtis distance of icenucleating communities contained in air, cloud, snow, rain and hail, b Venn diagram of common and unique genera, containing the ice nucleation protein

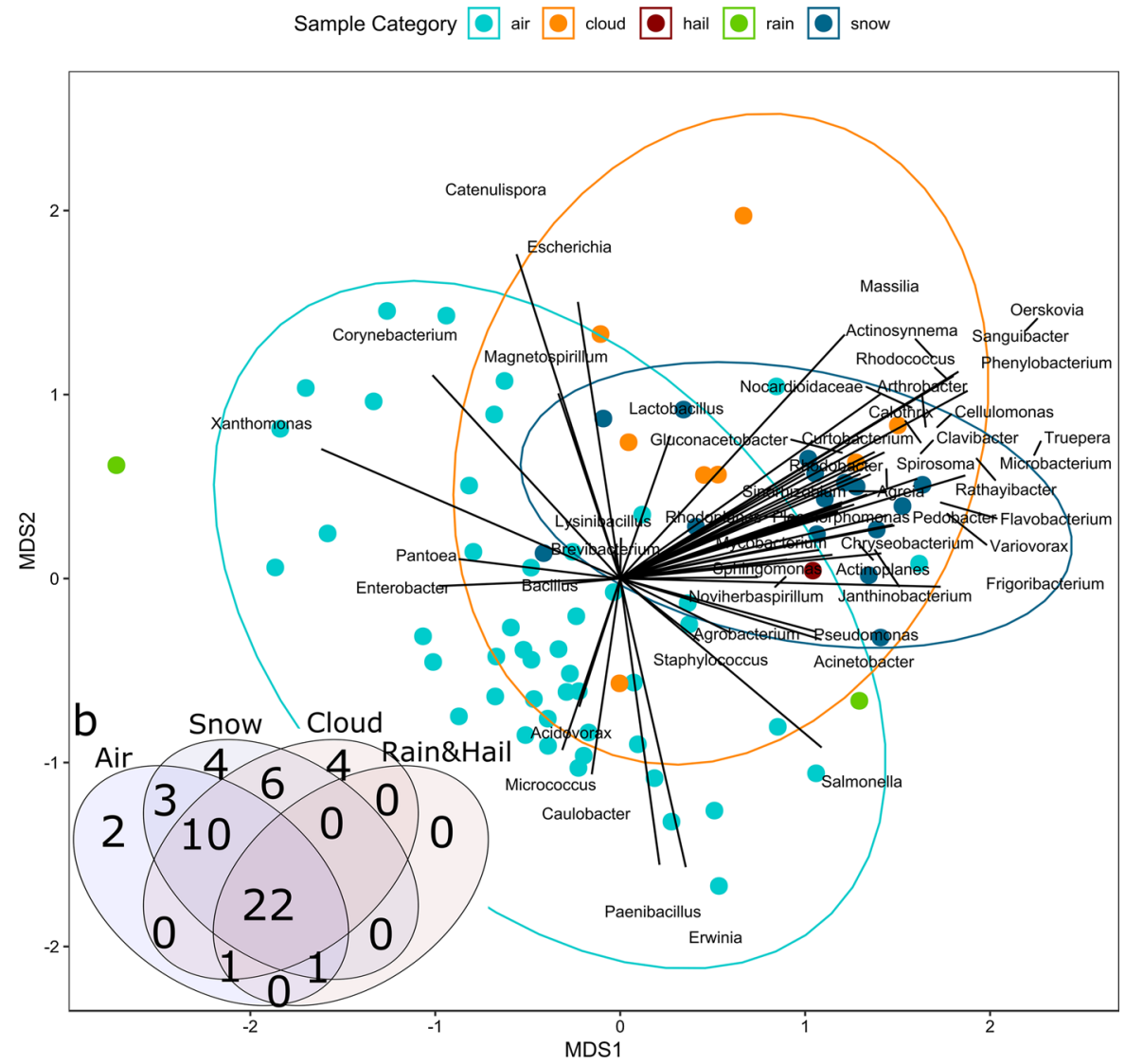

more mixing took place. August was also the time of strong precipitation events, highest humidity and highest temperature, thus highest thermodynamic capacity of air (Hänel 1976). In May, the PBL did not reach the sampling height, but PBL dynamics were more pronounced than in winter, due to higher temperatures and thus higher thermal convection processes.

\subsection{Seasonal changes in microbial abundance}

$16 \mathrm{~S}$ and 18S rRNA gene abundances lie within reported ranges of free tropospheric air and have been discussed in Els et al. (2019). 16S rRNA gene abundance showed highest variability in May, and highest 16S:18S ratio, indicating a filtering of fungi. High bacterial loads in spring and fall were previously reported at high elevations sites (Bowers et al. 2012). The overall 18S rRNA gene abundance was highest in November together with the lowest 16S:18S ratio. Fungal occurrences are strongly coupled to seasons and meteorological factors, depending on their lifestyle and sporulation strategy, and usually show high variations in air and cloud water (Pickersgill et al. 2017; Amato et al. 2007a, b). In May the valley was completely covered by fresh snow $(50 \mathrm{~cm}$ before sampling), and in November, the first snowfall on vegetation in the valley occurred on the day before sampling at the end of the growing season. Hence, when soils were dry, and particles are not bound strongly, together with less dense canopy and bare fields, aerosolization might be effectuated. One possibility for the high fungal abundance despite ongoing snowfall might be the impeded scavenging by snow crystals due to fungal hydrophobins. These proteins occur uniquely in mycelial fungi such as Ascomycetes or Basidiomycetes (Wösten 2001), which have been detected in the respective samples. Hydrophobins are crucial in a specific life stage of those fungi to grow aerial hyphae (Wösten et al. 1999). In August the fungal diversity was highest, as fungal sporulation is most active in summer, also thermal mixing is 
stronger, thus more spores were likely transported higher up in the atmosphere and injected to the free troposphere.

\subsection{Different seasonal dispersal patterns for bacterial and fungal communities}

Bacterial and fungal communities exhibited different patterns in changes in community structure throughout the year. Bacterial community structure differed significantly between summer and winter. Summer samples were dominated by ubiquitous, terrestrial associated genera like Paludibacter (Bacteriodetes), a gram-negative non-spore former involved in $\mathrm{NH}_{4}{ }^{+}$ oxidation (Zhang et al. 2018), Domibacillus (Firmicutes), a gram-positive, spore-forming, aerobic, nonmotile, rod-shaped organism isolated from deep-sea sediment (Sun and Sun 2016), ocean sediment (Sharma et al. 2014), mangrove sediment soil and macroalgae (Verma et al. 2017) and GPl (Acidobacteria), found in alpine grassland on the Tibetian Plateau (Yuan et al. 2014). Winter samples were more characterized by extremophile but omnipresent bacteria like Bifidobacterium (Actinobacteria) that can withstand a high range of $\mathrm{pH}$ (from 8 to 2) (Charteris et al. 1998), Vulcaniibacterium, a thermotolerant Gammaproteobacteria isolated from a geothermally heated soil (Yu et al. 2013), and Polaribacter (Bacteriodetes), which has been found in several arctic habitats (Cuthbertson et al. 2017; Harding et al. 2011; Collins et al. 2010). Differences in the winter to the summer microbiome (in SIMPER analysis) were driven by changes in abundance in Firmicutes such as Geobacillus and Tumebacillus. Geobacillus is a known thermo-resistant, spore-forming, ubiquitous Firmicute (Zeigler 2014). Tumebacillus (aerobic, spore-forming, gram-positive, rod-shaped, chemolithoautotroph) has been found in high Arctic Canadian permafrost (Steven et al. 2008) and was identified as one of the most abundant lineages in Australian dry lake aerosols (Munday et al. 2016) and heavy-haze days in Beijing, China (Yan et al. 2018). Firmicutes are recurrently characterized as highly abundant in free tropospheric air masses and longrange transport air masses (Smith et al. 2011, 2012; David et al. 2018; Els et al. 2019) and were enhanced in free tropospheric fall samples (Bowers et al. 2012). They are known to withstand hostile, even extraterrestrial conditions, like heat, cold, radiation or chemicals, by forming resistant endospores and are found in all investigated environments (Setlow 2006; Driks and Eichenberger 2016; Nicholson et al. 2000).

Fungi displayed a high seasonal variability with a range of different genera and phyla dominating the fungal composition at the different seasons. Sporulation strategy, dissemination adaption and lifestyledependent patterns are critical aspects for airborne fungal occurrence (Pickersgill et al. 2017). 53.9\% of all fungal genera were unique to August air masses. These samples were dominated by a large group of lichenized fungi (Miadlikowska et al. 2014) and the largest non-lichenous fungal group Leotiomycetes (Wang et al. 2006), whereas xerophilic and psychrophilic Eurotiomycetes (Geiser et al. 2006), highly resistant, yeast forming Saccharomycetes (Mühlhausen and Kollmar 2014), yeast forming Tremellomycetes (Liu et al. 2015) and xerophilic Wallemiomycetes (Zalar et al. 2005) were dominant in May. Tremellomycetes were also abundant in November, together with plant pathogenic, endophytic, saprophytic, epiphytic and lichenolous Sordariomycetes (Maharachchikumbura et al. 2016). In February, a time when potentially low sporulation happens, air abundant Agaricomycetes dominated. High wind speed in February yielded the second highest number of genera occurring in one season $(31.7 \%)$ and the communities were dominated by Agaricomycetes, which is ground and plant associated and known to form propagules being dispersed by the air and mainly connected to wet deposition (Hibbett et al. 2014; Prasher 2015). Additionally, compared to the other phyla, they are characterized by a relative small aerodynamic diameter which enables the spores to avoid faster sedimentation by dry deposition (Woo et al. 2018) and usually contribute a big share of airborne fungi (Pickersgill et al. 2017; FröhlichNowoisky et al. 2012). However, it has to be taken in to account that the choosen molecular primer and amplification method can result in an over- or underrepresentation of certain fungal classes (e.g., here highly abundant Agaricomycetes) or phyla (Blaalid et al. 2013).

\subsection{Comparison of community structure} and abundance in air and precipitation

Microorganisms precipitated with snow, hail or rain or being transported by clouds differ in their species 
composition from free tropospheric air masses and do not mirror the air community structure. They are distinct in composition, 16S:18S ratio, abundance and diversity from free-floating PBA. Clouds and snow generally had the highest diversity in both bacterial and fungal datasets, with atmosphere and rain being the least diverse.

Cloud bacterial communities were dominated by Proteobacteria, Actinobacteria and Bacteriodetes, which has also been observed in several cloud water studies from China, France, southern Africa and the USA (Jiaxian et al. 2019; Amato et al. 2017; Kourtev et al. 2011; Zhu et al. 2018; Evans et al. 2019). Fifteen of overall identified fungal genera were unique to clouds, whereas only $9 \%$ of bacterial genera were unique to clouds. The most abundant unique fungal cloud genera were Phaeomycocentrospora (Dothideomycetes), a large cosmopolitan genus of plantpathogenic leaf and fruit fungi (Crous et al. 2013). Further abundant unique cloud genera were Byssoloma (Lecarnomycetes), a lichen with pantropical spread and scattered temperate localities that was only recently first described in Sweden (Hermansson and Thor 2004), and Rhodosporidiobolus (Microbotryomycetes), which was found in arctic air and is associated with elevated phospholipase and hemolytic activity (Kirtsideli et al. 2017). Microbotrymycetes contain a range of psychrophilic yeasts. Thus, for those abundant unique cloud genera, their likely source and part of their dissemination strategy are long-range transport.

In air as compared to snow, cloud, hail and rain especially differences in Bray-Curtis distance were driven on genus level by Geobacillus (Firmicutes) and Aminobacter (Alphaproteobacteria), an organism found in various terrestrial environments (McDonald et al. 2005) that supports legume nodulation (Maynaud et al. 2012) and is capable of herbicide degradation (Schultz-Jensen et al. 2014). A further driving organism was Bosea (Alphaproteobacteria) an amoebaresisting bacteria which is associated with hospital water supply and intensive care ventilator-acquired pneumonia (Khamis et al. 2003; La Scola et al. 2003) and rhizosphere (Ahern et al. 2007). On phylum level, air was especially enhanced in Firmicutes. Hail was the only precipitation form not yielding significant differences to air at the respective season in unadjusted testing for bacteria and fungi in our dataset.
The bacterial abundance of fresh deposited snow, graupel or rain accounted for approximately $1 \times 10^{4} \mathrm{~mL}^{-1}$ or higher in various samples (Amato et al. 2007a, b; Bauer et al. 2002; Carpenter et al. 2000; Sattler et al. 2001; Segawa et al. 2005) and $10^{3}-$ $10^{4} \mathrm{~m}^{-3}$ for bacterial density in air at remote sites (Bauer et al. 2002; Burrows et al. 2009a, b). This implies a higher density of microbes in precipitation at a range of $1: 10^{6}$. PBA are more abundant in clouds than in the free atmosphere, and despite harsh conditions in clouds they might be more life-supporting due to the presence of water (Delort et al. 2017; Bauer et al. 2002). Clouds can highly vary in PBA abundance, with clouds formed during extreme events like desert dust uplift, containing higher than expected abundances (of $10^{5} \mathrm{~m}^{-3}$ bacteria like particles) (Maki et al. 2017). Further, the median of $16 \mathrm{~S}$ to $18 \mathrm{~S}$ ratio was lowest in clouds, suggesting a higher capacity of cloud doplets to hold fungi in clouds in comparison with air, snow or rain. The result of lowest ratio of bacteria to fungi in clouds is in accordance with Bauer et al. (2002), whose counts result in a bacteria-to-fungi ratio of 4.4 for clouds, 5 for snow and 16.4 for air. Bacteria could provide a surface area for the condensation of water vapor on the surface of aerosolized particulate matter (Jiaxian et al. 2019). In rain, 16S:18S ratio was highest, suggesting a separation mechanism for fungal spores before rain forms.

Rain was high in 16S rRNA gene abundance but low in $18 \mathrm{~S}$ abundance and in bacterial and fungal diversity. Air and rain were not significantly different in total bacterial air dataset, but in unadjusted testing in August dataset, fungi were significantly different in the total dataset.

Rain was the only precipitation form that yielded a significant difference when compared with another precipitation form in the total dataset, but it was not significant within the August dataset. However, the snow here was likely more influenced by melting, aging and aerial deposition. Rain was different to bacterial diversity in snow (unadjusted) and more significantly to fungi in snow.

Hail had the lowest $16 \mathrm{~S}$ : $18 \mathrm{~S}$ ratio, which might be due to the formation from cloud droplets that have also low $16 \mathrm{~S}: 18 \mathrm{~S}$ ratio, where spores might possibly get stuck to ice surface during sudden freezing. 


\subsection{Seasonal effects related to temperature}

A significant separation of air masses and precipitation samples was observed, and differences varied between seasons. In the winter seasons (November and February), the composition was similar in cloud and snow, but different to air, whereas in May bacterial composition of cloud and air was more similar, but pronouncedly different from snow. In May, the community of fungi in clouds featured high numbers of cold-adapted yeast and lichenous Tremellomycetes (Liu et al. 2015; Thomas-Hall et al. 2010) and plantpathogenic Dothideomycetes (Schoch et al. 2009; Hane et al. 2007) that were less abundant in air or snow. These results indicate that cold environmental conditions lead to comparable bacterial and fungal composition of snow and cloud, but different composition of air, while in the warmer conditions of May, air and cloud water were more similar in bacterial composition. Here we found the highest number of shared genera of cloud and air in one season (8.6\%) and highest total number of unique cloud genera (20.7\%) and outstandingly high amount of unique fungi in May cloud (63.6\%), with snow more different and a distinct fungal cloud composition. This indicates that warmer water vapor (but still negative ambient temperature in May around $-6.9{ }^{\circ} \mathrm{C}$ ) might have higher momentum and exchange or even promote a distinct composition by its living conditions. Also the composition of ice nucleation-active bacteria was similar in air and cloud in May with higher abundances of Pseudomonas, than in the other seasons, that can efficiently nucleate ice at a temperature of $-7{ }^{\circ} \mathrm{C}$ or lower (Maki et al. 1974).

Bacteria in air were more similar to precipitation in August (especially hail and air) than in the other months. This could be due to higher temperatures and humidity, facilitating more thermodynamic momentum leading to exchange and incorporation of humid air into cloud formation, similar life conditions in humid air and fast, on-site precipitation rather that distant transport.

August snow was lacking Firmicutes and had a low abundance of Chloroflexi, Planctomycetes and Cyanobacteria compared to snow from the other seasons. Here melting and accumulation processes might have played a role, as the snowpack was percolated with melt and rain water, and sediment form the molten snow pack and dry deposition was accumulated on the surface.

August fungal air samples were the closest to precipitation fungal samples. This might be due to the high abundance of fungi in August, but further also the higher humidity during this time, as fungal species actively discharge spores via liquid jets into the air, preferentially under humid conditions (Pringle et al. 2005; Elbert et al. 2007) and fungal variability being associated with humidity and rain frequency (Bowers et al. 2013). Fungal composition was shown to be significantly different in wet and dry deposition, suggesting taxon and size specific involvement in cloud condensation and precipitation (Woo et al. 2018).

\subsection{Selection processes and potential drivers}

The differences observed in community structure and abundance among the different sample types might be related to physical processes such as scavenging. In general, scavenging depends on the aerodynamic diameter, particle density but also chemical composition. Microbial cells can show hydrophilic or hydrophobic membranes which can alter their deposition substantially (Maria and Russell 2005). Cell surface hydrophobicity is often found in gram-negative bacteria (Krasowska and Sigler 2014). Rain or snow precipitation removes below-cloud aerosol particles and is a key process in aerosol chemical transport (Zhang et al. 2013). The scavenging coefficients or removal rates of particles are complex functions (Slinn 1983), but theoretical and experimental studies have shown that snow is a more efficient scavenger of particles than rain because of its larger surface area (Franz and Eisenreich 1998). The relative scavenging efficiency between snow and rain depends on particle sizes and precipitation intensity (Wang et al. 2014). For ultrafine and fine particles, the snow scavenging coefficient is predicted to be $\sim 10$ times larger than the rain scavenging coefficient at low precipitation rates (Wang et al. 2014). For rain, scavenging efficiency decreases with increasing particle size (Ardon-Dryer et al. 2015).

Clouds, fog and rain seem to represent media, where biological activity is significant due to the protection from desiccation and the potential use of chemical compounds in the aqueous solution (Deguillaume et al. 2008). Some bacteria can act as cloud 
condensation nuclei and produce biosurfactants that increase droplet size and cloud lifetime, counteract desiccation and allow water scavenging and thus facilitate widespread dispersal (Ahern et al. 2007).

PBA originate from surface aerosolization and thus represent lager potential sources than precipitation. Stricter selective processes are occurring for PBA to reach clouds, survive and be precipitated.

Rain does not scavenge too many organisms, as the residence time in the atmosphere is lower in rain. Raindrops have a smaller surface and are potentially less active in atmosphere interactions. Snow, in contrast, acts more like a sponge.

Hail is a unique form of precipitation that allows direct characterization of particles present during atmospheric ice nucleation, as the nucleation event is captured in the hail stone embryo (Michaud et al. 2014). The embryo is then caught by updraught and cycling in a storm cloud while accreting supercooled water during hailstone formation and thus represents a vertical intersection of cloud microbial composition (Knight and Knight 2001; Michaud et al. 2014). ŠantlTemkiv et al. (2013) observe an enrichment in plantassociated bacterial groups (Gammaproteobacteria, Sphingobacteria, Methylobacteria). Hail is one of the most extreme environments to live (Šantl-Temkiv et al. 2013).

\subsection{INP-containing bacteria are selected} for precipitation

Another mechanism that might explain variation in community structure is the capacity of certain organisms to carry out ice nucleation (IN). IN-particles active at $\geq-10{ }^{\circ} \mathrm{C}$ deplete twice as rapidly in precipitating clouds than other particles at this size (Stopelli et al. 2015).

There was a higher share of relative $\%$ reads of known ice nucleation-active bacteria present in all wet phases compared to air. Within the wet phases, snow had the hightest mean \% reads, whereas clouds showed a big variation thereof. It seems that a separation of IN-active reads occurred with higher shares occurring in precipitation.

Regarding seasonality, within air masses, the highest share of IN-active reads was reached in August, when also strongest precipitation occurred and samples were taken during rain events. IN- occurrence has been reported to increase during and after rain events (Huffman et al. 2013).

August precipitation was characterized by short but strong showers (compare supplement data Fig. S3) which have been observed to be significantly enhanced in IN in the first period of high intensity rain and hail, compared to continuous-type rain (Vali 1971). Ice nucleation-active bacteria were found to be relatively more abundant in rain than in air at the same site (Stephanie and Waturangi 2011). Christner et al. (2008a, b) report cumulative ice nuclei over several seasons to reach higher maximum values in rain (Louisiana rain 8-230 IN L ${ }^{-1}$, Alberta rain 20-600 IN $\mathrm{L}^{-1}$ ) compared to snow (mid-latitude snow 3-150 IN $\mathrm{L}^{-1}$ ). Cloud IN varied between 1 and $200 \mathrm{~mL}^{-1}$ at $-10{ }^{\circ} \mathrm{C}$ at Puy de Dome (Joly et al. 2014), thus ranging one order of magnitude higher than in rain or snow.

Christner et al. (2008a, b) estimated $0.4 \%$ of DNAcontaining cells in mid-latitude snowfall being INactive at $-7{ }^{\circ} \mathrm{C}$ to $-4{ }^{\circ} \mathrm{C}$, whereas in cloud water, estimates range between $0 \%$ and $1.5 \%$ IN-active bacteria at $-10{ }^{\circ} \mathrm{C}$ of total bacteria (Joly et al. 2014). In air, numbers were reported as $0.001 \%$ (Garcia et al. 2012; Xia et al. 2013) and showed significantly higher numbers in foggy air than in clear air (Bowers et al. 2009; Xia et al. 2013). Petters and Wright (2015) describe a variation in IN-concentration between rain, cloud water, hail and snow of up to five orders of magnitude.

Abundant rainfall was reported to drive nearsurface air IN-concentration with a positive correlation of rain intensity and IN-concentration, while strong snow fall had an attenuating effect on INconcentration (Conen et al. 2017).

In comparison, the values we estimate here based on relative abundance of reads of INP containing bacteria yield substantially higher numbers of INbacteria in air, cloud and precipitation. This could impact terrestrial biodiversity, with microbes landing in new environments faster (Morris et al. 2014), as our results imply, when precipitating.

The observed separation for community composition between air, snow, cloud and wet precipitation was also observed for IN-active bacteria, with clouds seeming like a mediator between air and snow in INcomposition. Only a few genera were unique to one sample type, the discrimination by NMDS was due to changes in relative abundance between sample types, 
which indicated an accumulation of most INP-containing bacteria in the wet phases, and only single species associated with air. Erwinia and Xanthomonas were unique in air in this dataset, though they are usually abundant in the environment, but also absent in other water-based IN-surveys (Du et al. 2017). Zweifel et al. (2012) found Erwinia and Pantoea in low frequencies, but recurringly in free tropospheric air samples.

The microbes present in clouds, snow and rain survived long-range transport, ice nucleation and cold cloud processes. Thus, it is likely that wet or snow deposited microbes will outperform their dry deposited counterparts in numbers and adaptions. As clouds often form far from the place where they precipitate and biological nucleators are frequently involved, their microbial composition is different from the present surface air microbiome.

\subsection{Precipitation is no proxy for free troposphere air communities}

Cáliz et al. (2018), who recently used snow as a proxy for air mass composition in the free troposphere, identified "airborne" Chytridiomycota as abundant in spring snow. The overall relative abundance of Chytridiomycota in all air samples was $0.01 \%$, compared to $2.49 \%$ in snow and $6.15 \%$ in rain but only $0.13 \%$ in hail and $0.22 \%$ in clouds in our dataset, indicating scavenging snow and rain precipitation. Bacteriodetes, a phylum identified by Cáliz et al. (2018) as abundant in snow, was identified as the one of three phyla driving most differences between air and snow (5.67\% air, $18.40 \%$ snow). While there is no doubt that microorganisms are aerosolized, incorporated in snow and then deposited (Harding et al. 2011), based on our dataset, selection at the phylum level occurs. Cyanobacteria were high in snow and cloud compared to air. They often contain a hygroscopic mucilaginous covering, that effects in density reduction and dynamic streamlining (Reynolds 2007), but might also absorb atmospheric moisture, why they become heavy and drop down (Sharma and Singh 2010). Air bacterial composition was found to be more similar to soil, decaying material, lichen and plant surface assemblages than to snow in a survey in Greenland, where snow featured higher abundances of
Beta- and Gammaproteobacteria and Bacteriodetes, while air was richer in Alphaproteobacteria, Cyanobacteria, Acidobacteria and Planctomycetes (Šantl-Temkiv et al. 2018).

Fog is known to have enriched concentrations of bacteria and yeast CFUs up to two orders of magnitude compared to clear air conditions, but no changes for mold CFUs (Fuzzi et al. 1997). Moreover, air samples derive from restricted altitudes, whereas the cloud samples can be addressed as a composite of this respective height including a thought black box from above. The composition of cloud chemistry and metabolically adapted cloud PBA community varies depending on the cloud origin (Deguillaume et al. 2014; Amato et al. 2017).

Evans et al. (2019) found that Shannon alpha diversity was greater in fog than clear conditions. Fog was more shaped by local sources than clear air, but also contained more remote marine signatures, indicating good conditions for long-range travel in clouds (Evans et al. 2019).

SIMPER analysis identified Janthinobacterium (Betaproteobacteria) and Chlorophyta (Chloroplast) as genera driving the difference between air and cloud and especially abundant in hail. Janthinobacterium in cloud water was found negatively correlated with $\mathrm{SO}_{2}$, $\mathrm{O}_{3}$, and particulate matter $\left(\mathrm{PM}_{10}\right.$ and $\left.\mathrm{PM}_{2.5}\right)$ and positively correlated with $\mathrm{K}^{+}$and $\mathrm{Mg}^{2+}$ (Jiaxian et al. 2019), which main sources are soil dust in big cloud droplets (Zhu et al. 2018). Janthinobacterium has antifungal properties (Rubio et al. 2018) and was found in high mountain lakes and Antarctica (Ahern et al. 2007) and alpine cryoconite, and is known for its psychrotolerant properties (Kim et al. 2012). It does fit the continental background location of Mount Sonnblick, where low concentrations of aerosol pollution markers (like $\mathrm{SO}_{2}$ or high PM) would be expected (Deguillaume et al. 2014).

Chlorophyta (i.e., microalgae) have previously been found in cloud samples (Urbano et al. 2011). The reason for that might also be the higher retention capacity in droplets than in air for bigger size PBA. The aerosolization of chlorophyta is especially correlated with relative humidity, but also with temperature, sunshine and wind speed (Sharma and Singh 2010). 


\section{Conclusion}

Significant differences were found in air microbial composition during different seasons, with pronounced summer and winter distinction in bacteria and strong discrepancies between all sampling events for fungi.

The season, thus temperature and humidity conditions, impact on free tropospheric microbial air composition and abundance, and should be kept in mind when interpreting single flight results. The differentiation between seasons was stronger pronounced in air than in precipitation, with rain being most different and variable of precipitation types, indicating distinct forces driving microbial fate in the air.

Microorganisms precipitated with snow, hail or rain or being transported by clouds differ in their species composition from free tropospheric air masses and do not mirror the air community structure. They are more diverse, potentially more viable due to the availability of water and as shown in this paper, distinct in composition, $16 \mathrm{~S}: 18 \mathrm{~S}$ ratio and abundance from freefloating PBA.

Hence, snow or cloud samples are no suitable proxies for free tropospheric air microbiome composition, as used by several studies, due to the findings that separation processes in aerosolization, transport and scavenging occur. The microbial composition of arriving precipitation or clouds represents only a part of the microbial air communities of the cumulative sources of origin.

Air can travel thousands of kilometers, but it is even more important to consider what is migrating in clouds and wet air masses, respectively, as the precipitation of PBA is more likely than sedimentation from clear air masses. Thus, precipitation might even have a bigger impact in ecosystem input due to higher microbe density when considering the ratio of cell numbers in precipitation compared to air being 1:106.

To understand global connectivity of bioaerosols, microbial migration and inoculation sources, a microbial air sampling network would be necessary, where precipitation cannot be used as a proxy but rather has to go alongside with air analyses.

With ongoing change in global water circulation, water availability and precipitation patterns this might have implications for microbial dispersal to ecosystems. Further, more continuous aerobiological monitoring in the free troposphere will be needed to understand interacting factors and feedbacks.

Acknowledgements Open access funding provided by University of Innsbruck and Medical University of Innsbruck. We thank for great support of three students: Christina Schweighofer, Karoline Wieser, Tamara Schober; the whole team of the Laboratoire Ampère of the École Centrale de Lyon, Elke Ludewig, Christian Meier, Alexander Hieden, Christoph Lotteraner and the whole team of the Sonnblick Observatory of the ZAMG and most important Klaus Unterberger.

Funding Open access funding provided by University of Innsbruck and Medical University of Innsbruck. This work received funding from the European Union's Horizon 2020 research and innovation program under the Marie SklodowskaCurie Grant No. 675546.

Data availability Raw sequences were submitted and are currently under evaluation at NCBI BioProject database under Project ID PRJNA516816 (http://www.ncbi.nlm.nih.gov/ bioproject/516816).

\section{Compliance with ethical standards}

Conflicts of interests The authors declare that they have no conflict of interest.

Open Access This article is distributed under the terms of the Creative Commons Attribution 4.0 International License (http:// creativecommons.org/licenses/by/4.0/), which permits unrestricted use, distribution, and reproduction in any medium, provided you give appropriate credit to the original author(s) and the source, provide a link to the Creative Commons license, and indicate if changes were made.

\section{References}

Adams, R. I., Bateman, A. C., Bik, H. M., \& Meadow, J. F. (2015). Microbiota of the indoor environment: A metaanalysis. Microbiome, 3(October), 49. https://doi.org/10. 1186/s40168-015-0108-3.

Ahern, H. E., Walsh, K. A., Hill, T. C. J., \& Moffett, B. F. (2007). Fluorescent pseudomonads isolated from Hebridean cloud and rain water produce biosurfactants but do not cause ice nucleation. Biogeosciences, 4(1), 115-124. https://doi.org/10.5194/bg-4-115-2007.

Alsved, M., Holm, S., Christiansen, S., Smidt, M., Ling, M., Boesen, T., et al. (2018). Effect of aerosolization and drying on the viability of pseudomonas syringae cells. Frontiers in Microbiology. https://doi.org/10.3389/fmicb. 2018.03086.

Amato, P., Hennebelle, R., Magand, O., Sancelme, M., Delort, A.-M., Barbante, C., et al. (2007a). Bacterial characterization of the snow cover at Spitzberg, Svalbard. FEMS 
Microbiology Ecology, 59(2), 255-264. https://doi.org/10. 1111/j.1574-6941.2006.00198.x.

Amato, P., Joly, M., Besaury, L., Oudart, A., Taib, N., Moné, A. I., et al. (2017). Active microorganisms thrive among extremely diverse communities in cloud water. PLoS ONE, 12(8), e0182869. https://doi.org/10.1371/journal.pone. 0182869.

Amato, P., Ménager, M., Sancelme, M., Laj, P., Mailhot, G., \& Delort, A.-M. (2005). Microbial population in cloud water at the Puy de Dôme: Implications for the chemistry of clouds. Atmospheric Environment, 39(22), 4143-4153. https://doi.org/10.1016/j.atmosenv.2005.04.002.

Amato, P., Parazols, M., Sancelme, M., Mailhot, G., Laj, P., \& Delort, A.-M. (2007b). An important oceanic source of micro-organisms for cloud water at the Puy de Dôme (France). Atmospheric Environment, 41(37), 8253-8263. https://doi.org/10.1016/j.atmosenv.2007.06.022.

Ardon-Dryer, K., Huang, Y.-W., \& Cziczo, D. J. (2015). Laboratory studies of collection efficiency of sub-micrometer aerosol particles by cloud droplets on a single-droplet basis. Atmospheric Chemistry and Physics, 15(16), 9159-9171. https://doi.org/10.5194/acp-15-9159-2015.

Bauer, H., Heinrich, G., Regina, H., Kasper-Giebl, A., Reischl, G., Zibuschka, F., et al. (2003). Airborne bacteria as cloud condensation nuclei: Bacteria as cloud condensation nuclei. Journal of Geophysical Research: Atmospheres. https://doi.org/10.1029/2003JD003545.

Bauer, H, Kasper-Giebl, A. Löflund, M. Giebl, H. Hitzenberger, R., Zibuschka, F. \& Puxbaum, H. (2002). The contribution of bacteria and fungal spores to the organic carbon content of cloud water, precipitation and aerosols. Atmospheric Research. In 2nd international conference on fog and fog collection, 64 (1-4), pp. 109-19. https://doi.org/10.1016/ S0169-8095(02)00084-4.

Bianco, A., Voyard, G., Deguillaume, L., Mailhot, G., \& Brigante, M. (2016). Improving the characterization of dissolved organic carbon in cloud water: Amino acids and their impact on the oxidant capacity. Scientific Reports, 6(November), 37420. https://doi.org/10.1038/srep37420.

Blaalid, R., Kumar, S., Nilsson, R. H., Abarenkov, K., Kirk, P. M., \& Kauserud, H. (2013). ITS1 versus ITS2 as DNA metabarcodes for fungi. Molecular Ecology Resources, 13(2), 218-224. https://doi.org/10.1111/1755-0998.12065.

Bowers, R. M., Clements, N., Emerson, J. B., Wiedinmyer, C., Hannigan, M. P., \& Fierer, N. (2013). Seasonal variability in bacterial and fungal diversity of the near-surface atmosphere. Environmental Science and Technology, 47(21), 12097-12106. https://doi.org/10.1021/es402970s.

Bowers, R. M., Lauber, C. L., Wiedinmyer, C., Hamady, M., Hallar, A. G., Fall, R., et al. (2009). Characterization of airborne microbial communities at a high-elevation site and their potential to act as atmospheric ice nuclei. Applied and Environmental Microbiology, 75(15), 5121-5130. https://doi.org/10.1128/AEM.00447-09.

Bowers, R. M., McCubbin, I. B., Hallar, A. G., \& Fierer, N. (2012). Seasonal variability in airborne bacterial communities at a high-elevation site. Atmospheric Environment, 50(April), 41-49. https://doi.org/10.1016/j.atmosenv. 2012.01.005.

Bowers, R. M., McLetchie, S., Knight, R., \& Fierer, N. (2011). Spatial variability in airborne bacterial communities across land-use types and their relationship to the bacterial communities of potential source environments. The ISME Journal, 5(4), 601-612. https://doi.org/10.1038/ismej. 2010.167.

Brown, J. K. M., \& Hovmøller, M. S. (2002). Aerial dispersal of pathogens on the global and continental scales and its impact on plant disease. Science, 297(5581), 537-541. https://doi.org/10.1126/science.1072678.

Brunet, Y., Wéry, N., \& Galès, A. (2017). Short-scale transport of bioaerosols. Microbiology of Aerosols. https://doi.org/ 10.1002/9781119132318.ch2b.

Burge, H. A. (2002). An update on pollen and fungal spore aerobiology. The Journal of Allergy and Clinical Immunology, 110(4), 544-552.

Burrows, T., Butler, P., Jöckel, H., Tost, A., Kerkweg, U. Pöschl, \& Lawrence, M. G. (2009a). Bacteria in the global atmosphere-part 2: Modeling of emissions and transport between different ecosystems. Atmospheric Chemistry and Physics, 9(23), 9281-9297.

Burrows, W. E., Lawrence, M. G., \& Pöschl, U. (2009b). Bacteria in the global atmosphere-part 1: Review and synthesis of literature data for different ecosystems. Atmospheric Chemistry and Physics, 9(23), 9263-9280.

Cáliz, J., Triadó-Margarit, X., Camarero, L., \& Casamayor, E. O. (2018). A long-term survey unveils strong seasonal patterns in the airborne microbiome coupled to general and regional atmospheric circulations. Proceedings of the National Academy of Sciences; . https://doi.org/10.1073/ pnas. 1812826115.

Caporaso, J. Gregory, Kuczynski, J., Stombaugh, J., Bittinger, K., Bushman, F. D., Costello, E. K., et al. (2010). QIIME allows analysis of high-throughput community sequencing data. Nature Methods, 7(5), 335-336. https://doi.org/10. 1038/nmeth.f.303.

Carotenuto, F., Georgiadis, T., Gioli, B., Leyronas, C., Morris, C. E., Nardino, M., et al. (2017). Measurements and modeling of surface-atmosphere exchange of microorganisms in Mediterranean grassland. Atmospheric Chemistry and Physics, 17(24), 14919-14936. https://doi.org/10. 5194/acp-17-14919-2017.

Carpenter, E. J., Lin, S., \& Capone, D. G. (2000). Bacterial activity in south pole snow. Applied and Environmental Microbiology, 66(10), 4514-4517.

Charteris, W. P., Kelly, P. M., Morelli, L., \& Collins, J. K. (1998). Development and application of an in vitro methodology to determine the transit tolerance of potentially probiotic Lactobacillus and Bifidobacterium species in the upper human gastrointestinal tract. Journal of Applied Microbiology, 84(5), 759-768. https://doi.org/10. 1046/j.1365-2672.1998.00407.x.

Christner, B. C., Morris, C. E., Foreman, C. M., Cai, R., \& Sands, D. C. (2008a). Ubiquity of biological ice nucleators in snowfall. Science, 319(5867), 1214. https://doi.org/10. 1126/science. 1149757.

Christner, B. C., Rongman, C., Morris, C. E., McCarter, K., Foreman, C. M., Skidmore, M., et al. (2008b). Geographical, seasonal, and precipitation chemistry influence in the abundance and activity of biological ice nucleators in rain and snow. Proceedings of the National Academy of Sciences of the United States of America, 105(48), 18854-18859. 
Clot, B. (2003). Trends in airborne pollen: An overview of 21 years of data in Neuchâtel (Switzerland). Aerobiologia, 19(3), 227-234. https://doi.org/10.1023/B:AERO. 0000006572.53105 .17$.

Collins, R. E., Rocap, G., \& Deming, J. W. (2010). Persistence of bacterial and archaeal communities in sea ice through an arctic winter. Environmental Microbiology, 12(7), 1828-1841. https://doi.org/10.1111/j.1462-2920.2010. 02179.x.

Conen, F., Eckhardt, S., Gundersen, H., Stohl, A., \& Yttri, K. E. (2017). Rainfall drives atmospheric ice-nucleating particles in the coastal climate of Southern Norway. Atmospheric Chemistry and Physics, 17(18), 11065-11073. https://doi.org/10.5194/acp-17-11065-2017.

Crous, P. W., Braun, U., Hunter, G. C., Wingfield, M. J., Verkley, G. J. M., Shin, H.-D., et al. (2013). Phylogenetic lineages in pseudocercospora. Studies in Mycology, Phytopathogenic, 75(June), 37-114. https://doi.org/10.3114/ $\operatorname{sim} 0005$.

Cuthbertson, L., Amores-Arrocha, H., Malard, L. A., Els, N., Sattler, B., \& Pearce, D. A. (2017). Characterisation of Arctic bacterial communities in the air above Svalbard. Biology, 6(2), 29. https://doi.org/10.3390/biology6020029.

Damialis, A., Vokou, D., Gioulekas, D., \& Halley, J. M. (2015). Long-term trends in airborne fungal-spore concentrations: A comparison with pollen. Fungal Ecology, 13(February), 150-156. https://doi.org/10.1016/j.funeco.2014.09.010.

Deguillaume, L., Charbouillot, T., Joly, M., Vaïtilingom, M., Parazols, M., Marinoni, A., et al. (2014). Classification of clouds sampled at the Puy de Dôme (France) Based on 10 Yr of monitoring of their physicochemical properties. Atmospheric Chemistry and Physics, 14(3), 1485-1506. https://doi.org/10.5194/acp-14-1485-2014.

Deguillaume, L., Leriche, M., Amato, P., Ariya, P. A., Delort, A.-M., Pöschl, U., et al. (2008). Microbiology and atmospheric processes: Chemical interactions of primary biological aerosols. Biogeosciences, 5(4), 1073-1084. https:// doi.org/10.5194/bg-5-1073-2008.

DeLeon-Rodriguez, N., Lathem, T. L., Rodriguez-R, L. M., Barazesh, J. M., Anderson, B. E., Beyersdorf, A. J., et al. (2013). Microbiome of the upper troposphere: Species composition and prevalence, effects of tropical storms, and atmospheric implications. Proceedings of the National Academy of Sciences, 110(7), 2575-2580. https://doi.org/ 10.1073/pnas. 1212089110.

Delort, A., Delort, A. M., Vaïtilingom, M., Joly, M., Amato, P., Wirgot, N., et al. (2017). Clouds: A transient and stressing habitat for microorganisms. In C. Chénard \& F. M. Lauro (Eds.), Microbial ecology of extreme environments (pp. 215-245). Cham: Springer. https://doi.org/10.1007/978-3319-51686-8_10.

Di Giulio, M., Grande, R., Di Campli, E., Di Bartolomeo, S., \& Cellini, L. (2010). Indoor air quality in university environments. Environmental Monitoring and Assessment, 170(1-4), 509-517. https://doi.org/10.1007/s10661-0091252-7.

Dommergue, A., Amato, P., Tignat-Perrier, R., Magand, O., Thollot, A., Joly, M., et al. (2019). Methods to investigate the global atmospheric microbiome. Frontiers in Microbiology. https://doi.org/10.3389/fmicb.2019.00243.
Driks, A, \& Eichenberger, P. (Eds.) 2016. Ecology of bacillaceae. In The bacterial spore: From molecules to systems (pp. 59-85). American Society of Microbiology. https:// doi.org/10.1128/microbiolspec.TBS-0017-2013.

Du, R., Du, P., Lu, Z., Ren, W., Liang, Z., Qin, S., et al. (2017). Evidence for a missing source of efficient ice nuclei. Scientific Reports, 7, 1. https://doi.org/10.1038/srep39673.

Edgar, R. C., Haas, B. J., Clemente, J. C., Quince, C., \& Knight, R. (2011). UCHIME improves sensitivity and speed of chimera detection. Bioinformatics, 27(16), 2194-2200. https://doi.org/10.1093/bioinformatics/btr381.

Elbert, W., Taylor, P. E., Andreae, M. O., \& Pöschl, U. (2007). Contribution of fungi to primary biogenic aerosols in the atmosphere: Wet and dry discharged spores, carbohydrates, and inorganic ions. Atmospheric Chemistry and Physics, 7(17), 4569-4588. https://doi.org/10.5194/acp-74569-2007.

Els, N., Baumann-Stanzer, K., Larose, C., Vogel, T. M., \& Sattler, B. (2019). Beyond the planetary boundary layer: Bacterial and fungal vertical biogeography at Mount Sonnblick. Austria. Geo: Geography and Environment. https://doi.org/10.1002/geo2.69. in press.

Elster, J., Delmas, R. J., Petit, J.-R., \& Reháková, K. (2007). Composition of microbial communities in aerosol, snow and ice samples from remote glaciated areas (Antarctica, Alps, Andes). Biogeosciences Discussions, 4(3), 1779-1813.

Evans, S. E., Elias Dueker, M., Robert Logan, J., \& Weathers, K. C. (2019). The biology of fog: Results from coastal Maine and Namib Desert reveal common drivers of fog microbial composition. Science of the Total Environment, 647(January), 1547-1556. https://doi.org/10.1016/j.scitotenv. 2018.08.045

Fahlgren, C., Hagström, Å., Nilsson, D., \& Zweifel, U. L. (2010). Annual variations in the diversity, viability, and origin of airborne bacteria. Applied and Environment Microbiology, 76(9), 3015-3025. https://doi.org/10.1128/ AEM.02092-09.

Fang, Z., Guo, W., Zhang, J., \& Lou, X. (2018). Influence of heat events on the composition of airborne bacterial communities in urban ecosystems. International Journal of Environmental Research and Public Health, 15(10), 2295. https://doi.org/10.3390/ijerph15102295.

Fierer, N., Liu, Z., Rodríguez-Hernández, M., Knight, R., Henn, M., \& Hernandez, M. T. (2008). Short-term temporal variability in airborne bacterial and fungal populations. Applied and Environmental Microbiology, 74(1), 200-207. https://doi.org/10.1128/AEM.01467-07.

Franz, T. P., \& Eisenreich, S. J. (1998). 'Snow scavenging of polychlorinated biphenyls and polycyclic aromatic hydrocarbons in minnesota. Environmental Science \& Technology, 10, 1. https://doi.org/10.1021/es970601z.

Franzetti, A., Gandolfi, I., Gaspari, E., Ambrosini, R., \& Bestetti, G. (2011). Seasonal variability of bacteria in fine and coarse urban air particulate matter. Applied Microbiology and Biotechnology, 90(2), 745-753. https://doi.org/10. 1007/s00253-010-3048-7.

Fröhlich-Nowoisky, J., Burrows, S. M., Xie, Z., Engling, G., Solomon, P. A., Fraser, M. P., et al. (2012). Biogeography in the air: Fungal diversity over land and oceans. 
Biogeosciences, 9(3), 1125-1136. https://doi.org/10.5194/ bg-9-1125-2012.

Fuzzi, S., Mandrioli, P., \& Perfetto, A. (1997). Fog droplets-an atmospheric source of secondary biological aerosol particles. Atmospheric Environment, 31(2), 287-290. https:// doi.org/10.1016/1352-2310(96)00160-4.

Garcia, E., Hill, Thomas C. J., Prenni, A. J., DeMott, P. J., Franc, G. D., \& Kreidenweis, S. M. (2012). Biogenic ice nuclei in boundary layer air over two U.S. High plains agricultural regions: Biogenic ice nuclei over two agricultural regions. Journal of Geophysical Research: Atmospheres. https:// doi.org/10.1029/2012JD018343.

Gat, D., Mazar, Y., Cytryn, E., \& Rudich, Y. (2017). Origindependent variations in the atmospheric microbiome community in eastern mediterranean dust storms. Environmental Science and Technology, 51(12), 6709-6718. https://doi.org/10.1021/acs.est.7b00362.

Geiser, D. M., Gueidan, C., Miadlikowska, J., Lutzoni, F., Kauff, F., Hofstetter, V., et al. (2006). Eurotiomycetes: Eurotiomycetidae and chaetothyriomycetidae. Mycologia, 98(6), 1053-1064. https://doi.org/10.1080/15572536. 2006.11832633.

Gioulekas, D., Balafoutis, C., Damialis, A., Papakosta, D., Gioulekas, G., \& Patakas, D. (2004). Fifteen years' record of airborne allergenic pollen and meteorological parameters in Thessaloniki, Greece. International Journal of Biometeorology, 48(3), 128-136. https://doi.org/10.1007/ s00484-003-0190-2.

Gomes, E. A., Kasuya, M. C. M., Barros, E. G. D., Borges, A. C., \& Araújo, E. F. (2002). Polymorphism in the internal transcribed spacer (ITS) of the ribosomal DNA of 26 isolates of ectomycorrhizal fungi. Genetics and Molecular Biology, 25(4), 477-483. https://doi.org/10.1590/S141547572002000400018.

Griffin, D. W. (2007). Atmospheric movement of microorganisms in clouds of desert dust and implications for human health. Clinical Microbiology Reviews, 20(3), 459-477. https://doi.org/10.1128/CMR.00039-06.

Hagan, M. E., Klotz, S. A., Bartholomew, W., Potter, L., \& Nelson, M. (1995). A pseudoepidemic of rhodotorula rubra: A marker for microbial contamination of the bronchoscope. Infection Control and Hospital Epidemiology, 16(12), 727-728.

Hamaoui-Laguel, L., Vautard, R., Liu, L., Solmon, F., Viovy, N., Khvorostyanov, D., et al. (2015). Effects of climate change and seed dispersal on airborne ragweed pollen loads in Europe. Nature Climate Change, 5(8), 766-771. https://doi.org/10.1038/nclimate2652.

Hane, J. K., Lowe, Rohan G. T., Solomon, P. S., Tan, K.-C., Schoch, C. L., Spatafora, J. W., et al. (2007). Dothideomycete-plant interactions illuminated by genome sequencing and EST analysis of the wheat pathogen Stagonospora nodorum. The Plant Cell, 19(11), 3347-3368. https://doi.org/10.1105/tpc.107.052829.

Hänel, G. (1976). The properties of atmospheric aerosol particles as functions of the relative humidity at thermodynamic equilibrium with the surrounding moist air. In $\mathrm{H}$. E. Landsberg \& J. Van Mieghem (Eds.), Advances in geophysics (Vol. 19, pp. 73-188). Amsterdam: Elsevier. https://doi.org/10.1016/S0065-2687(08)60142-9.
Harding, T., Jungblut, A. D., Lovejoy, C., \& Vincent, W. F. (2011). Microbes in high arctic snow and implications for the cold biosphere. Applied and Environmental Microbiology, 77(10), 3234-3243. https://doi.org/10.1128/AEM. 02611-10.

Hermansson, J., \& Thor, G. (2004). Byssoloma subdiscordans and usnea substerilis new to sweden. Graphis Scripta, 15, 3.

Hibbett, D. S., Bauer, R., Binder, M., Giachini, A. J., Hosaka, K., Justo, A., et al. (2014). 14 Agaricomycetes. In D. McLaughlin \& J. W. Spatafora (Eds.), Systematics and evolution. The Mycota (A comprehensive treatise on fungi as experimental systems for basic and applied research) (Vol. 7A). Berlin: Springer. https://doi.org/10.1007/978-3642-55318-9_14.

Honeyman, A. S., Day, M. L., \& Spear, J. R. (2018). Regional fresh snowfall microbiology and chemistry are driven by geography in storm-tracked events, Colorado, USA. Peer J, 6, e5961. https://doi.org/10.7717/peerj.5961.

Huffman, J. A., Prenni, A. J., DeMott, P. J., Pöhlker, C., Mason, R. H., Robinson, N. H., et al. (2013). High concentrations of biological aerosol particles and ice nuclei during and after rain. Atmospheric Chemistry and Physics, 13(13), 6151-6164. https://doi.org/10.5194/acp-13-6151-2013.

Innocente, E., Squizzato, S., Visin, F., Facca, C., Rampazzo, G., Bertolini, V., et al. (2017). Influence of seasonality, air mass origin and particulate matter chemical composition on airborne bacterial community structure in the Po Valley, Italy. The Science of the Total Environment, 593-594(September), 677-687. https://doi.org/10.1016/j. scitotenv.2017.03.199.

Jäger, S. (2000). Ragweed (Ambrosia) sensitisation rates correlate withthe amount of inhaled airborne pollen. A 14-Year Studyin Vienna, Austria. Aerobiologia, 16(1), 149-153. https://doi.org/10.1023/A:1007603321556.

Jang, G. I., Hwang, C. Y., \& Cho, B. C. (2018). Effects of heavy rainfall on the composition of airborne bacterial communities. Frontiers of Environmental Science \& Engineering, 12(2), 12. https://doi.org/10.1007/s11783-018-1008-0.

Jeon, E. M., Kim, H. J., Jung, K., Kim, J. H., Kim, M. Y., Kim, Y. P., et al. (2011). Impact of Asian dust events on airborne bacterial community assessed by molecular analyses. Atmospheric Environment, 45(25), 4313-4321. https://doi. org/10.1016/j.atmosenv.2010.11.054.

Jiaxian, P., Shumin, Z., Kai, X., Junyang, Z., Yao Chuanhe, L., Senlin, Z. W., et al. (2019). Diversity of bacteria in cloud water collected at a national atmospheric monitoring station in Southern China. Atmospheric Research, 218(April), 176-182. https://doi.org/10.1016/j.atmosres.2018.12.004.

Jimenez-Sanchez, C., Hanlon, R., Aho, K. A., Powers, C., Morris, C. E., \& Schmale, D. G. (2018). Diversity and ice nucleation activity of microorganisms collected with a small unmanned aircraft system (SUAS) in France and the United States. Frontiers in Microbiology, 9, 1. https://doi. org/10.3389/fmicb.2018.01667.

Joly, M., Amato, P., Deguillaume, L., Monier, M., Hoose, C., \& Delort, A.-M. (2014). Direct quantification of total and biological ice nuclei in cloud water. Atmospheric Chemistry and Physics Discussions, 14(3), 3707-3731. https:// doi.org/10.5194/acpd-14-3707-2014. 
Kelley, S. T., \& Gilbert, J. A. (2013). Studying the microbiology of the indoor environment. Genome Biology, 14(February), 202. https://doi.org/10.1186/gb-2013-14-2-202.

Khamis, A., Colson, P., Raoult, D., \& La Scola, B. (2003). Usefulness of RpoB gene sequencing for identification of Afipia and Bosea Species, including a strategy for choosing discriminative partial sequences. Applied and Environment Microbiology, 69(11), 6740-6749. https://doi.org/10.1128/ AEM.69.11.6740-6749.2003.

Kim, J. S., Shin, S. C., Hong, S. G., Lee, Y. M., Lee, H., Lee, J., et al. (2012). Genome sequence of Janthinobacterium Sp. Strain PAMC 25724, isolated from alpine glacier cryoconite. Journal of Bacteriology, 194(8), 2096. https://doi. org/10.1128/JB.00096-12.

Kirtsideli, I. Y., Vlasov, D. Y., Abakumov, D. V., Barantsevich, E. P., Novozhilov, Y. K., Krylenkov, V. A., et al. (2017). Airborne fungi in arctic settlement Tiksi (Russian Arctic, Coast of the Laptev Sea). Czech Polar Reports, 7(2), 300-310. https://doi.org/10.5817/CPR2017-2-29.

Klindworth, A., Pruesse, E., Schweer, T., Peplies, J., Quast, C., Horn, M., et al. (2013). Evaluation of general 16S ribosomal RNA gene PCR primers for classical and next-generation sequencing-based diversity studies. Nucleic Acids Research, 41(1), e1. https://doi.org/10.1093/nar/gks808.

Knight, C. A., \& Knight, N. C. (2001). Hailstorms. In C. A. Doswell (Ed.), Severe convective storms (pp. 223-254)., Meteorological Monographs Boston: American Meteorological Society. https://doi.org/10.1007/978-1-935704-065_6.

Kõljalg, U., Henrik Nilsson, R., Abarenkov, K., Tedersoo, L., Taylor, Andy F. S., Bahram, M., et al. (2013). Towards a unified paradigm for sequence-based identification of fungi. Molecular Ecology, 22(21), 5271-5277. https://doi. org/10.1111/mec. 12481.

Kourtev, P. S., Hill, K. A., Shepson, P. B., \& Konopka, A. (2011). Atmospheric cloud water contains a diverse bacterial community. Atmospheric Environment, 45(30), 5399-5405. https://doi.org/10.1016/j.atmosenv.2011.06. 041.

Krasowska, A., \& Sigler, K. (2014). How microorganisms use hydrophobicity and what does this mean for human needs? Frontiers in Cellular and Infection Microbiology. https:// doi.org/10.3389/fcimb.2014.00112.

Lallement, A., Besaury, L., Tixier, E., Sancelme, M., Amato, P., Vinatier, V., et al. (2018). Potential for phenol biodegradation in cloud waters. Biogeosciences, 15(18), 5733-5744. https://doi.org/10.5194/bg-15-5733-2018.

Larose, C., Berger, S., Ferrari, C., Navarro, E., Dommergue, A., Schneider, D., et al. (2010). Microbial sequences retrieved from environmental samples from seasonal arctic snow and meltwater from Svalbard, Norway. Extremophiles, 14(2), 205-212. https://doi.org/10.1007/s00792-009-0299-2.

Liu, X.-Z., Wang, Q.-M., Göker, M., Groenewald, M., Kachalkin, A. V., Lumbsch, H. T., et al. (2015). Towards an integrated phylogenetic classification of the tremellomycetes. Studies in Mycology, 81(June), 85-147. https:// doi.org/10.1016/j.simyco.2015.12.001.

Lotteraner, C., \& Piringer, M. (2016). Mixing-height time series from operational ceilometer aerosol-layer heights. Boundary-Layer Meteorology, 161(2), 265-287. https:// doi.org/10.1007/s10546-016-0169-2.
Maharachchikumbura, Sajeewa S. N., Hyde, K. D., Gareth Jones, E. B., McKenzie, E. H. C., Bhat, J. D., Dayarathne, M. C., et al. (2016). Families of sordariomycetes. Fungal Diversity, 79(1), 1-317. https://doi.org/10.1007/s13225016-0369-6.

Maki, L. R., Galyan, E. L., Chang-Chien, M.-M., \& Caldwell, D. R. (1974). Ice nucleation induced by pseudomonas syringae. Applied Microbiology, 28(3), 456-459.

Maki, T., Hara, K., Iwata, A., Lee, K. C., Kawai, K., Kai, K., et al. (2017). Variations in airborne bacterial communities at high altitudes over the Noto Peninsula (Japan) in Response to Asian dust events. Atmos. Chem. Phys. Discuss., 2017(January), 1-32. https://doi.org/10.5194/acp2016-1095.

Maria, S. F., \& Russell, L. M. (2005). Organic and inorganic aerosol below-cloud scavenging by suburban New Jersey precipitation. Environmental Science and Technology, 39(13), 4793-4800.

Martinez Arbizu, P. (2017). pairwiseAdonis: Pairwise multilevel comparison using adonis. $\mathrm{R}$ package version 0.0.1. https://github.com/pmartinezarbizu/pairwiseAdonis.

Masella, A. P., Bartram, A. K., Truszkowski, J. M., Brown, D. G., \& Neufeld, J. D. (2012). PANDAseq: Paired-End assembler for illumina sequences. BMC Bioinformatics, 13(1), 31. https://doi.org/10.1186/1471-2105-13-31.

Maynaud, G., Willems, A., Soussou, S., Vidal, C., Mauré, L., Moulin, L., et al. (2012). Molecular and phenotypic characterization of strains nodulating anthyllis vulneraria in mine tailings, and proposal of Aminobacter anthyllidis Sp. Nov., the first definition of aminobacter as legume-nodulating bacteria. Systematic and Applied Microbiology, 35(2), 65-72. https://doi.org/10.1016/j.syapm.2011.11. 002.

McDonald, I. R., Kämpfer, P., Topp, E., Warner, K. L., Cox, M. J., Hancock, T. L. C., et al. (2005). Aminobacter ciceronei Sp. Nov. and Aminobacter lissarensis Sp. Nov., isolated from various terrestrial environments. International Journal of Systematic and Evolutionary Microbiology, 55(5), 1827-1832. https://doi.org/10.1099/ijs.0.63716-0.

McMurdie, P. J., \& Holmes, S. (2013). Phyloseq: An R package for reproducible interactive analysis and graphics of microbiome census data. PLoS ONE, 8(4), e61217. https:// doi.org/10.1371/journal.pone.0061217.

Miadlikowska, J., Kauff, F., Högnabba, F., Oliver, J. C., Molnár, K., Fraker, E., et al. (2014). A multigene phylogenetic synthesis for the class lecanoromycetes (Ascomycota): 1307 fungi representing 1139 infrageneric taxa, 317 genera and 66 families. Molecular Phylogenetics and Evolution. https://doi.org/10.1016/j.ympev.2014.04.003.

Michaud, A. B., Dore, J. E., Deborah Leslie, W., Lyons, B., Sands, D. C., \& Priscu, J. C. (2014). Biological ice nucleation initiates hailstone formation. Journal of Geophysical Research: Atmospheres, 119(21), 12186-12197. https://doi.org/10.1002/2014JD022004.

Möhler, O., Demott, P. J., Vali, G., \& Levin, Z. (2007). Microbiology and atmospheric processes: The role of biological particles in cloud physics. Biogeosciences, 4(6), 1059-1071.

Morris, C. E., Franz Conen, J., Huffman, A., Phillips, V., Pöschl, U., \& Sands, D. C. (2014). Bioprecipitation: A feedback cycle linking earth history, ecosystem dynamics and land 
use through biological ice nucleators in the atmosphere. Global Change Biology, 20(2), 341-351. https://doi.org/ 10.1111/gcb.12447.

Mühlhausen, S., \& Kollmar, M. (2014). Molecular phylogeny of sequenced saccharomycetes reveals polyphyly of the alternative yeast codon usage. Genome Biology and Evolution, 6(12), 3222-3237. https://doi.org/10.1093/gbe/ evu152.

Munday, C., De Deckker, P., Tapper, N., O’Loingsigh, T., \& Allison, G. (2016). Characterizing bacterial assemblages in sediments and aerosols at a dry lake bed in australia using high-throughput sequencing. Aerobiologia, 32(4), 581-593. https://doi.org/10.1007/s10453-015-9407-1.

Nicholson, W. L., Munakata, N., Horneck, G., Melosh, H. J., \& Setlow, P. (2000). Resistance of bacillus endospores to extreme terrestrial and extraterrestrial environments. $\mathrm{Mi}$ crobiology and Molecular Biology Reviews, 64(3), 548-572. https://doi.org/10.1128/MMBR.64.3.548-572. 2000.

Oksanen, J., Blanchet, G, Friendly, F., Kindt, M., Legendre, R., McGlinn, P., Dan Minchin, P. R. et al. (2018). Vegan: Community ecology package (version 2.5-1). https:// CRAN.R-project.org/package=vegan.

Øvreås, L., \& Torsvik, V. (1998). Microbial diversity and community structure in two different agricultural soil communities. Microbial Ecology, 36(3), 303-315.

Paramonov, M., Grönholm, T., \& Virkkula, A. (2011). Belowcloud scavenging of aerosol particles by snow at an urban site in Finland. Boreal Environment Research, 16, 18.

Park, H. K., Han, J.-H., Joung, Y., Cho, S.-H., Kim, S.-A., \& Kim, S. B. (2014). Bacterial diversity in the indoor air of pharmaceutical environment. Journal of Applied Microbiology, 116(3), 718-727. https://doi.org/10.1111/jam. 12416.

Petters, M. D., \& Wright, T. P. (2015). Revisiting ice nucleation from precipitation samples. Geophysical Research Letters, 42(20), 8758-8766. https://doi.org/10.1002/ 2015 GL065733.

Pickersgill, D. A., Wehking, J., Paulsen, H., Thines, E., Pöschl, U., Fröhlich-Nowoisky, J., et al. (2017). Lifestyle dependent occurrence of airborne fungi. Biogeosciences Discuss., 2017(November), 1-20. https://doi.org/10.5194/bg2017-452.

Polymenakou, P. N. (2012). Atmosphere: A source of pathogenic or beneficial microbes? Atmosphere, 3(1), 87-102. https://doi.org/10.3390/atmos3010087.

Pouzet, G., Peghaire, E., Aguès, M., Baray, J.-L., Conen, F., \& Amato, P. (2017). Atmospheric processing and variability of biological ice nucleating particles in precipitation at Opme, France. Atmosphere, 8(11), 229. https://doi.org/10. 3390/atmos8110229.

Prasher, I. B. (2015). Wood-rotting non-gilled Agaricomycetes of Himalayas. Berlin: Springer.

Prévost-Bouré, C., Nicolas, R. C., Dequiedt, S., Mougel, C., Lelièvre, M., Jolivet, C., et al. (2011). Validation and application of a PCR primer set to quantify fungal communities in the soil environment by real-time quantitative PCR. PLoS ONE, 6(9), e24166. https://doi.org/10.1371/ journal.pone.0024166.
Pringle, A., Patek, S. N., Fischer, M., Stolze, J., \& Money, N. P. (2005). The captured launch of a ballistospore. Mycologia, 97(4), 866-871.

R Core Team. (2015). R: A language and environment for statistical computing. $R$ foundation for statistical compution. $R$ : A language and environment for statistical computing. https://www.R-project.org.

Reynolds, C. S. (2007). Variability in the provision and function of mucilage in phytoplankton: Facultative responses to the environment. Hydrobiologia, 578(1), 37-45. https://doi. org/10.1007/s10750-006-0431-6.

Rognes, T., Flouri, T., Nichols, B., Quince, C., \& Mahé, F. (2016). VSEARCH: A versatile open source tool for metagenomics. PeerJ, 4(October), e2584. https://doi.org/ 10.7717/peerj.2584.

Rotach, M. W., Gohm, A., Lang, M. N., Leukauf, D., Stiperski, I., \& Wagner, J. S. (2015). On the vertical exchange of heat, mass, and momentum over complex, mountainous terrain. Frontiers in Earth Science. https://doi.org/10.3389/feart. 2015.00076.

Rubio, A. O., Kupferberg, S. J., García, V. V., Ttito, A., Shepack, A., \& Catenazzi, A. (2018). Widespread occurrence of the antifungal cutaneous bacterium janthinobacterium lividum on andean water frogs threatened by fungal disease. Diseases of Aquatic Organisms, 131(3), 233-238. https://doi.org/10.3354/dao03298.

Šantl-Temkiv, T., Finster, K., Dittmar, T., Hansen, B. M., Thyrhaug, R., Nielsen, N. W., et al. (2013). Hailstones: A window into the microbial and chemical inventory of a storm cloud. PLoS ONE, 8(1), e53550. https://doi.org/10. 1371/journal.pone.0053550.

Šantl-Temkiv, T., Gosewinkel, U., Starnawski, P., Lever, M., \& Finster, K. (2018). Aeolian dispersal of bacteria in southwest greenland: Their sources, abundance, diversity and physiological states. FEMS Microbiology Ecology. https:// doi.org/10.1093/femsec/fiy031.

Sattler, B., Puxbaum, H., \& Psenner, R. (2001). Bacterial growth in supercooled cloud droplets. Geophysical Research Letters, 28(2), 239-242. https://doi.org/10.1029/ 2000 GL011684.

Schmale, D. G., \& Ross, S. D. (2015). Highways in the sky: Scales of atmospheric transport of plant pathogens. Annual review of Phytopathology, 53(1), 591-611. https://doi.org/ 10.1146/annurev-phyto-080614-115942.

Schoch, C. L., Crous, P. W., Groenewald, J. Z., Boehm, E. W. A., Burgess, T. I., de Gruyter, J., et al. (2009). A classwide phylogenetic assessment of dothideomycetes. Studies in Mycology, A phylogenetic re-evaluation of, 64(January), 1-15. https://doi.org/10.3114/sim.2009.64.01.

Schultz-Jensen, N., Knudsen, B. E., Frkova, Z., Aamand, J., Johansen, T., Thykaer, J., et al. (2014). Large-scale bioreactor production of the herbicide-degrading Aminobacter sp. strain MSH1. Applied Microbiology and Biotechnology, 98(5), 2335-2344. https://doi.org/10.1007/ s00253-013-5202-5.

Scola, L., Bernard, I. B., Greub, G., Khamis, A., Martin, C., \& Raoult, D. (2003). Amoeba-resisting bacteria and ventilator-associated pneumonia. Emerging Infectious Diseases, 9(7), 815-821. https://doi.org/10.3201/eid0907.030065.

Segawa, T., Miyamoto, K., Ushida, K., Agata, K., Okada, N., \& Kohshima, S. (2005). Seasonal change in bacterial flora 
and biomass in mountain snow from the Tateyama Mountains, Japan, analyzed by 16S RRNA gene sequencing and real-time PCR. Applied and Environmental Microbiology, 71(1), 123-130. https://doi.org/10.1128/ AEM.71.1.123-130.2005.

Setlow, P. (2006). Spores of Bacillus subtilis: Their resistance to and killing by radiation, heat and chemicals. Journal of Applied Microbiology, 101(3), 514-525. https://doi.org/10. 1111/j.1365-2672.2005.02736.x.

Sharma, A., Dhar, S. K., Prakash, O., Vemuluri, V. R., Thite, V., \& Shouche, Y. S. (2014). Description of Domibacillus indicus Sp. Nov., isolated from ocean sediments and emended description of the genus Domibacillus. International Journal of Systematic and Evolutionary Microbiology, 64(Pt 9), 3010-3015. https://doi.org/10.1099/ijs.0. 064295-0.

Sharma, N. K., \& Singh, S. (2010). Differential aerosolization of algal and cyanobacterial particles in the atmosphere. Indian Journal of Microbiology, 50(4), 468-473. https://doi. org/10.1007/s12088-011-0146-x.

Slinn, W. G. N. (1983). Precipitation scavenging. In D. Raderson (Ed.), Atmospheric sciences and power production (Chap. 11). Washington, DC: Division of Biomedical Environmental Research, U.S. Department of Energy.

Smith, D. J. (2012). Long range transport of microorganisms in the upper atmosphere. Seattle: University of Washington.

Smith, D. J., Griffin, D. W., \& Jaffe, D. A. (2011). The high life: Transport of microbes in the atmosphere. Eos, Transactions American Geophysical Union, 92(30), 249-250. https://doi.org/10.1029/2011EO300001.

Smith, D. J., Jaffe, D. A., Birmele, M. N., Griffin, D. W., Schuerger, A. C., Hee, J., et al. (2012). Free tropospheric transport of microorganisms from Asia to North America. Microbial Ecology, 64(4), 973-985. https://doi.org/10. 1007/s00248-012-0088-9.

Smith, D. J., Ravichandar, J. D., Jain, S., Griffin, D. W., Hongbin, Yu., Tan, Q., et al. (2018). Airborne bacteria in earth's lower stratosphere resemble taxa detected in the troposphere: Results from a New NASA Aircraft Bioaerosol Collector (ABC). Frontiers in Microbiology. https:// doi.org/10.3389/fmicb.2018.01752.

Smith, D. J., Timonen, H. J., Jaffe, D. A., Griffin, D. W., Birmele, M. N., Perry, K. D., et al. (2013). Intercontinental dispersal of bacteria and archaea by transpacific winds. Applied and Environmental Microbiology, 79(4), 1134-1139. https://doi.org/10.1128/AEM.03029-12.

Sofiev, M., Belmonte, J., Gehrig, R., zquierdo, R., Smith, M., Dahl, Å., et al. (2013). Airborne pollen transport. In M. Sofiev \& K.-C. Bergmann (Eds.), Allergenic pollen: A review of the production, release, distribution and health impacts (pp. 127-159). Dordrecht: Springer. https://doi. org/10.1007/978-94-007-4881-1_5.

Stephanie, \& Waturangi, D. E. (2011). Distribution of ice nucleation-active (INA) bacteria from rain-water and air. HAYATI Journal of Biosciences, 18(3), 108-112. https:// doi.org/10.4308/hjb.18.3.108.

Steven, B., Chen, M. Q., Greer, C. W., Whyte, L. G., \& Niederberger, T. D. (2008). Tumebacillus permanentifrigoris gen. Nov., Sp. Nov., an aerobic, spore-forming bacterium isolated from canadian high arctic permafrost. International Journal of Systematic and Evolutionary
Microbiology, 58(6), 1497-1501. https://doi.org/10.1099/ ijs.0.65101-0.

Stohl, A., Eckhardt, S., Forster, C., James, P., Spichtinger, N., \& Seibert, P. (2002). A replacement for simple back trajectory calculations in the interpretation of atmospheric trace substance measurements. Atmospheric Environment, 36(29), 4635-4648. https://doi.org/10.1016/S13522310(02)00416-8.

Stopelli, E., Conen, F., Morris, C. E., Herrmann, E., Bukowiecki, N., \& Alewell, C. (2015). Ice nucleation active particles are efficiently removed by precipitating clouds. Scientific Reports. https://doi.org/10.1038/srep16433.

Sun, Q.-L., \& Sun, L. (2016). Description of Domibacillus iocasae Sp. Nov., Isolated from Deep-Sea sediment, and emended description of the genus Domibacillus. International Journal of Systematic and Evolutionary Microbiology, 66(2), 982-987. https://doi.org/10.1099/ijsem.0. 000823.

Taylor, D. Lee, Walters, W. A., Lennon, N. J., Bochicchio, J., Andrew Krohn, J., Caporaso, G., et al. (2016). Accurate estimation of fungal diversity and abundance through improved lineage-specific primers optimized for illumina amplicon sequencing. Applied and Environmental Microbiology, 82(24), 7217-7226. https://doi.org/10.1128/AEM. 02576-16.

Techy, L., Schmale, D. G., \& Woolsey, C. A. (2010). Coordinated aerobiological sampling of a plant pathogen in the lower atmosphere using two autonomous unmanned aerial vehicles. Journal of Field Robotics, 27(3), 335-343. https://doi.org/10.1002/rob.20335.

Temkiv, T. Š., Finster, K., Hansen, B. M., Nielsen, N. W., \& Karlson, U. G. (2012). The microbial diversity of a storm cloud as assessed by hailstones. FEMS Microbiology Ecology, 81(3), 684-695. https://doi.org/10.1111/j.15746941.2012.01402.x.

Thomas-Hall, S. R., Turchetti, B., Buzzini, P., Branda, E., Boekhout, T., Theelen, B., et al. (2010). Cold-adapted yeasts from Antarctica and the Italian Alps-Description of three novel species: Mrakia robertii Sp. Nov., Mrakia blollopis Sp. Nov. and Mrakiella niccombsii Sp. Nov. Extremophiles, 14(1), 47-59. https://doi.org/10.1007/ s00792-009-0286-7.

Urbano, R., Palenik, B., Gaston, C. J., \& Prather, K. A. (2011). Detection and phylogenetic analysis of coastal bioaerosols using culture dependent and independent techniques. Biogeosciences, 8(2), 301-309. https://doi.org/10.5194/bg-8301-2011.

Vali, G. (1971). Freezing nucleus content of hail and rain in alberta. Journal of Applied Meteorology, 10(1), 73-78. https://doi.org/10.1175/1520-0450(1971)010\%3c0073: FNCOHA\%3e2.0.CO;2.

Verma, A., Ojha, A. K., Dastager, S. G., Natarajan, R., Mayilraj, S., \& Krishnamurthi, S. (2017). Domibacillus mangrovi Sp. Nov. and Domibacillus epiphyticus Sp. Nov., isolated from marine habitats of the central West Coast of India. International Journal of Systematic and Evolutionary Microbiology, 67(8), 3063-3070. https://doi.org/10.1099/ ijsem.0.002085.

Wang, Q., Garrity, G. M., Tiedje, J. M., \& Cole, J. R. (2007). Naive bayesian classifier for rapid assignment of RRNA sequences into the new bacterial taxonomy. Applied and 
Environmental Microbiology, 73(16), 5261-5267. https:// doi.org/10.1128/AEM.00062-07.

Wang, Z., Johnston, P. R., Takamatsu, S., Spatafora, J. W., \& Hibbett, D. S. (2006). Toward a phylogenetic classification of the leotiomycetes based on RDNA data. Mycologia, 98(6), 1065-1075. https://doi.org/10.1080/15572536. 2006.11832634.

Wang, X., Zhang, L., \& Moran, M. D. (2014). Development of a new semi-empirical parameterization for below-cloud scavenging of size-resolved aerosol particles by both rain and snow. Geoscientific Model Development, 7(3), 799-819. https://doi.org/10.5194/gmd-7-799-2014.

Weil, T., De Filippo, C., Albanese, D., Donati, C., Pindo, M., Pavarini, L., et al. (2017). Legal immigrants: Invasion of alien microbial communities during winter occurring desert dust storms. Microbiome, 5(March), 32. https://doi. org/10.1186/s40168-017-0249-7.

Weiss, S., Zhenjiang Zech, X., Peddada, S., Amir, A., Bittinger, K., Gonzalez, A., et al. (2017). Normalization and microbial differential abundance strategies depend upon data characteristics. Microbiome, 5(March), 27. https://doi.org/ 10.1186/s40168-017-0237-y.

Wekker, D., Kossmann, M., \& Kossmann, M. (2015). Convective boundary layer heights over mountainous terrainA review of concepts. Frontiers in Earth Science. https:// doi.org/10.3389/feart.2015.00077.

Wickham, H. (2009). Ggplot2: Elegant graphics for data analysis. New-York: Springer. http://ggplot2.org.

Woo, C., An, C., Siyu, X., Yi, S.-M., \& Yamamoto, N. (2018). Taxonomic diversity of fungi deposited from the atmosphere. The ISME Journal, 12(8), 2051. https://doi.org/10. 1038/s41396-018-0160-7.

Wösten, H. A. (2001). Hydrophobins: Multipurpose proteins. Annual Review of Microbiology, 55, 625-646. https://doi. org/10.1146/annurev.micro.55.1.625.

Wösten, Han A. B., van Wetter, M.-A., Lugones, L. G., van der Mei, H. C., Busscher, H. J., \& Wessels, Joseph G. H. (1999). How a fungus escapes the water to grow into the air. Current Biology, 9(2), 85-88. https://doi.org/10.1016/ S0960-9822(99)80019-0.

Xia, Y., Conen, F., \& Alewell, C. (2013). Total bacterial number concentration in free tropospheric air above the alps. Aerobiologia, 29(1), 153-159. https://doi.org/10.1007/ s10453-012-9259-x.

Yan, D., Zhang, T., Jing, S., Zhao, L.-L., Wang, H., Fang, X.M., et al. (2018). Structural variation in the bacterial community associated with airborne particulate matter in Beijing, China, during Hazy and Nonhazy Days. Applied and Environment Microbiology, 84(9), e00004-e00018. https://doi.org/10.1128/AEM.00004-18.
Yu, T.-T., Zhou, E.-M., Yin, Y.-R., Yao, J.-C., Ming, H., Dong, L., et al. (2013). Vulcaniibacterium tengchongense Gen. Nov., Sp. Nov. Isolated from a geothermally heated soil sample, and reclassification of lysobacter thermophilus Wei et Al. 2012 as Vulcaniibacteriumthermophilum Comb. Nov. Antonie van Leeuwenhoek, 104(3), 369-376. https://doi.org/10.1007/s10482-013-9959-4.

Yuan, Y., Si, G., Wang, J., Luo, T., \& Zhang, G. (2014). Bacterial community in alpine grasslands along an altitudinal gradient on the Tibetan Plateau. FEMS Microbiology Ecology, 87(1), 121-132. https://doi.org/10.1111/15746941.12197.

Zalar, P., Sybren de Hoog, G., Schroers, H.-J., Frank, J. M., \& Gunde-Cimerman, N. (2005). Taxonomy and phylogeny of the xerophilic genus Wallemia (Wallemiomycetes and Wallemiales, Cl. et Ord. Nov.). Antonie van Leeuwenhoek, 87(4), 311-328. https://doi.org/10.1007/s10482-004-6783$\mathrm{x}$.

Zeigler, D. R. (2014). The geobacillus paradox: Why is a thermophilic bacterial genus so prevalent on a mesophilic planet? Microbiology, 160(Pt_1), 1-11. https://doi.org/10. 1099/mic.0.071696-0.

Zhang, Y.-B., Wang, Y.-L., Li, W.-H., Bao, L.-N., Huang, X.H., Huang, B., et al. (2018). Biogas emission from an anaerobic reactor. Aerosol and Air Quality Research, 18(6), 1493-1502. https://doi.org/10.4209/aaqr.2018.05. 0169.

Zhang, L., Wang, X., Moran, M. D., \& Feng, J. (2013). Review and uncertainty assessment of size-resolved scavenging coefficient formulations for below-cloud snow scavenging of atmospheric aerosols. Atmospheric Chemistry and Physics, 13(19), 10005-10025. https://doi.org/10.5194/ acp-13-10005-2013.

Zhu, C., Chen, J., Wang, X., Li, J., Wei, M., Caihong, X., et al. (2018). Chemical composition and bacterial community in size-resolved cloud water at the summit of Mt. Tai, China. Aerosol and Air Quality Research, 18(1), 1-14. https://doi. org/10.4209/aaqr.2016.11.0493.

Ziello, C., Sparks, T. H., Estrella, N., Belmonte, J., Bergmann, K. C., Bucher, E., et al. (2012). Changes to airborne pollen counts across Europe. PLoS ONE, 7(4), e34076. https://doi. org/10.1371/journal.pone.0034076.

Zikova, N., \& Zdimal, V. (2016). Precipitation scavenging of aerosol particles at a rural site in the Czech Republic. Tellus B: Chemical and Physical Meteorology, 68(1), 27343. https://doi.org/10.3402/tellusb.v68.27343.

Zweifel, U. L., Hagström, Å., Holmfeldt, K., Thyrhaug, R., Geels, C., Frohn, L. M., et al. (2012). High bacterial 16S RRNA gene diversity above the atmospheric boundary layer. Aerobiologia, 28(4), 481-498. https://doi.org/10. 1007/s10453-012-9250-6. 